\title{
DEEP PRODUCTION WELL FOR GEOTHERMAL DIRECT-USE HEATING OF A LARGE COMMERCIAL GREENHOUSE, RADIUM SPRINGS, RIO GRANDE RIFT, NEW MEXICO
}

\author{
FINAL REPORT \\ USDOE CONTRACT \\ DE-FG07-99ID13747
}

\author{
PREPARED BY \\ JAMES C. WITCHER
}

Las Cruces, NM

SUBMITTED BY

ALEX R. MASSON, INC.

Linwood, KS

\author{
SUBMITTED TO \\ U.S. DEPARTMENT OF ENERGY \\ IDAHO FALLS, IDAHO
}

FEBRUARY 2001 


\section{DISCLAIMER}

This report was prepared to document work sponsored by the United States Government. Neither the United States nor its agent, the United States Department of Energy (DOE), nor any Federal employees, makes any warranty, express or implied, or assumes any legal liability or responsibility for the accuracy, completeness, or usefulness of any information, apparatus, product, or process disclosed, or represents that its use would not infringe privately owned rights. Reference herein to any specific commercial product, process, or service by trade name, trademark, manufacturer, or otherwise, does not necessarily constitute or imply its endorsement, recommendation, or favoring by the United States Government or any agency thereof. The views and opinions of authors expressed herein do not necessarily state or reflect those of the United States Government or any agency thereof. 


\section{ACKNOWLEDGEMENTS}

This report was prepared with the support of the U. S. Department of Energy (DOE) under contract DE-FG07-99ID13747 to Alex R. Masson, Inc.

Michael Henzler, manager of the Masson Radium Springs greenhouse is thanked for all of his assistance and enthusiasm. Michael Henzler's assistant Cindy is most thanked for her assistance with daily reports to the BLM by helping with the FAX and copy machine in the greenhouse office. Bill Rickard and Wendell Howard of the Resource Group provided key well site and engineering support for the project and played important roles in the success of the Masson 36 well. Dick Hahman is thanked for his geologic assistance. Russ Jentgen, Joe Torres, Russ Lummus, and Rich Estabrook of the BLM are thanked for their assistance with the Environmental Assessment and constructive discussions on drilling permits and Sundry Notices. Calvin Chavez of the New Mexico State Engineers Office also provided valuable input on permitting issues and water data. Don Pearson and Mick Peterson of Southwest Geophysical Surveys are thanked for their scheduling patience and subsequent coordination of timely borehole geophysical surveys. Comments and review by Ray Fortuna and Jay Nathwani, USDOE are much appreciated. 


\section{TABLE OF CONTENTS}

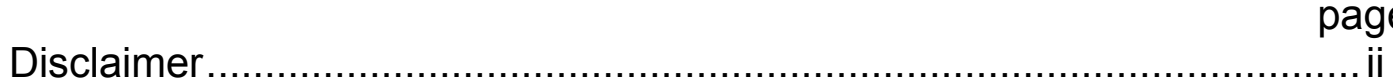

Acknowledgements ................................................................... ii

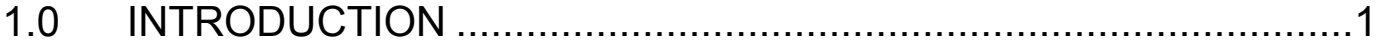

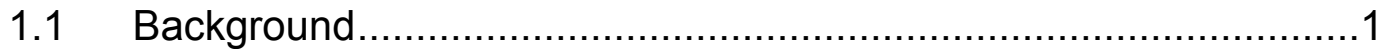

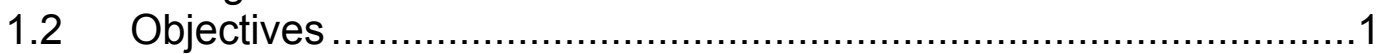

1.3 Site Selection and Well Design Considerations ..............................

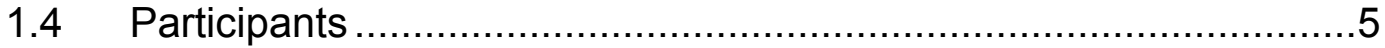

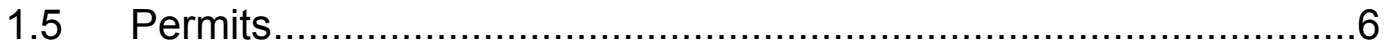

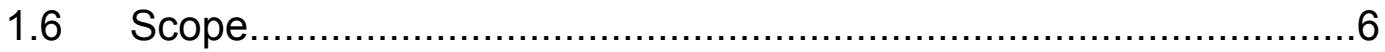

2.0 DRILLING AND SITE OPERATIONS …...............................



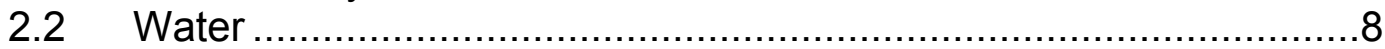

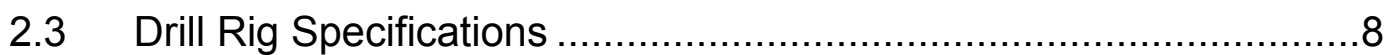

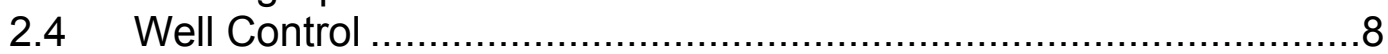

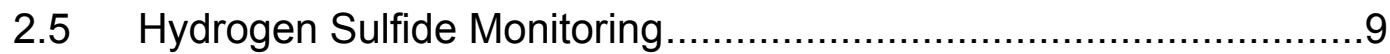

2.6 Well Site Geology and Operations Monitoring ...............................

2.7 Drilling Summary and Analysis ..............................................10

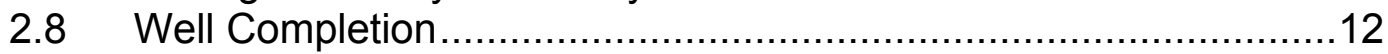

2.9 Geophysical and Temperature Logging ...................................14

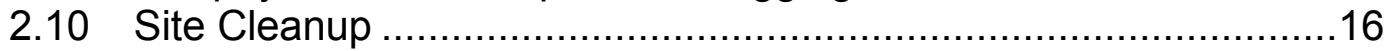

3.0 GEOLOGY AND GEOTHERMAL RESOURCE …......................17

3.1 Geology of Masson 36 Well ....................................................17

3.2 Thermal Regime of the Masson 36 Well ..................................22

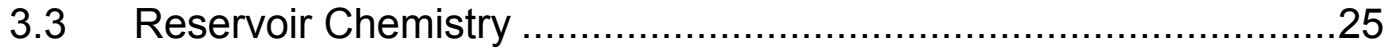

4.0 CONCLUSIONS AND RECOMMENDATIONS ............................26

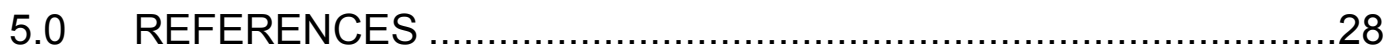




\section{FIGURES}

page

$1 \quad$ Location Map of the Masson 36 Well ............................................

$2 \quad$ Pre-Surface Casing Temperature and Geophysical Logs .............18

3 Post Drilling Gamma and Temperature Logs..............................19

$4 \quad$ Electric Logs of the 460 to 793 Feet Interval.............................20

5 Composite Graph of Temperature Logs and BHT Measurements.24 


\section{TABLES}

page

1 Daily Footage and Activity Log of Masson 36 Well ......................13

2 Masson 36 Well Completion Specifications ................................14

3 List of Temperature and Geophysical Logs ..............................15 


\section{APPENDICES}

1 Summary Well History of the Masson 36 Well

2 Summary Geologic Log of Masson 36 Well

3 Laboratory Analysis of Water and Other Samples

4 Dowell/Schlumberger Surface Casing Cement Report 



\subsection{INTRODUCTION}

\section{$1.1 \quad$ Background}

Expansion of a large commercial geothermally-heated greenhouse is underway and requires additional geothermal fluid production. This report discusses the results of a cost-shared U. S. Department of Energy (DOE) and A. R. Masson, Inc. drilling project designed to construct a highly productive geothermal production well for expansion of the large commercial greenhouse at Radium Springs. The well should eliminate the potential for future thermal breakthrough from existing injection wells and the inducement of inflow from shallow cold water aquifers by geothermal production drawdown in the shallow reservoir. An 800 feet deep production well, Masson 36, was drilled on a U. S. Bureau of Land Management (BLM) Geothermal Lease NM-3479 at Radium Springs adjacent to the A. R. Masson Radium Springs Farm commercial greenhouse 15 miles north of Las Cruces in Dona Ana County, New Mexico just west of Interstate 25 near the east bank of the Rio Grande. (Figure 1). The area is in the Rio Grande rift, a tectonically-active region with high heat flow, and is one of the major geothermal provinces in the western United States (Seager and Morgan, 1979; and White and Williams, 1975).

\subsection{Objectives}

The major objective of the Masson 36 well was to obtain $190{ }^{\circ} \mathrm{F}$ fluids at 1,500 gallons per minute (gpm) from a deep-confined reservoir. The objective of producing from the deep reservoir which is confined by a thick, 


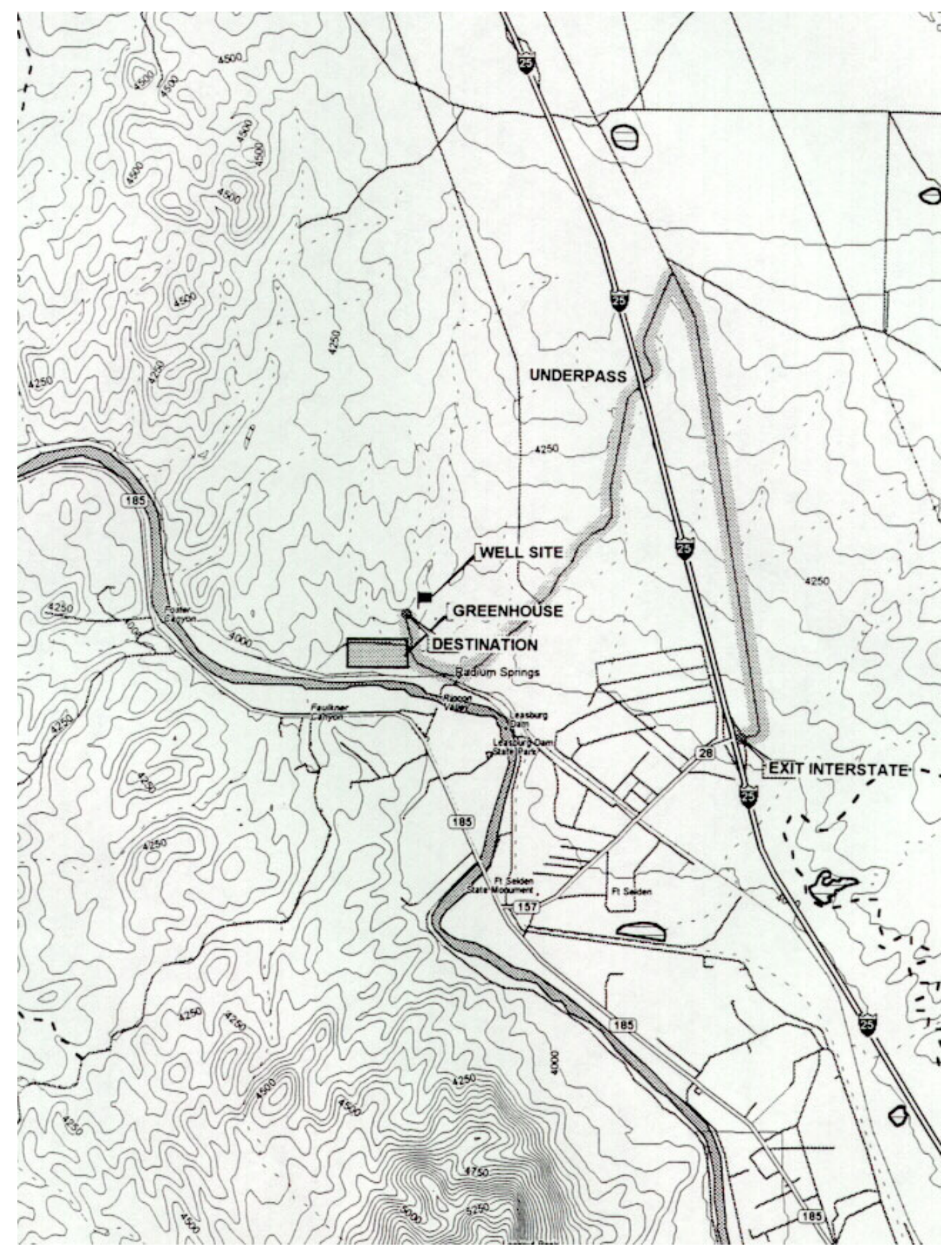

Figure 1. Location Map of the Masson 36 Well. 
clay-rich aquitard, is to practically eliminate direct communication with the shallow cold water aquifers and the Rio Grande from geothermal production pumping in the future. Current geothermal production and injection forms a probable flow couplet that is contained in a shallow and fractured rhyolite intrusion. The couplet and intrusion are hydraulically-connected with nearby shallow cold water aquifers. Therefore, the third primary objective is to avoid drilling across the shallow rhyolite reservoir or seal it off during well construction, if it is encountered, so that only deeper water is produced. All of these objectives were apparently achieved with the Masson 36 well.

\subsection{Site Selection and Well Design Considerations}

The currently produced shallow reservoir at Radium Springs is contained in a fractured rhyolite intrusion with probable Oligocene age of limited areal extent and volume that intrudes across a thick Eocene aquitard, the Palm Park Formation (Seager, 1975). The fractured rhyolite is in hydraulic communication with nearby cold alluvial aquifers (Gross, 1987).

With the current shallow production-injection well couplet, decreases in temperature are experienced in late winter and early spring as the greenhouse facility has grown from 4 acres to about 17 acres since 1987 . This decrease in temperature is probably from the combined affects of drawdown that encourages infiltration of cold water from the Rio Grande and sub adjacent aquifers and from cool injected fluids via the injection wells.

The shallow reservoir contains 150 to $162{ }^{\circ} \mathrm{F}$ sodium chloride water with a variable total dissolved solids (TDS) of around 3,300 milligrams per liter (mg/L) (Witcher, 1988). Current production is from two wells less than 300 feet depth, completed in fractured rhyolite. These wells were drilled by rotary air hammer. Two injection wells, approximately 1,000 feet distance from the production wells, accommodate about $400 \mathrm{gpm}$ of $100{ }^{\circ} \mathrm{F}$ water. The injection 
wells are located in the local outflow plume of the fractured rhyolite host, while the production wells are located over the local upflow plume. The upflow plume is a "geohydrologic window" of rhyolite that acts as a conduit across the Palm Park aquitard and allows upflow out of a deeper much larger reservoir (Witcher, 1988; and Ross and Witcher, 1998).

Two deep (8,000 and 9,000 feet depth) wells drilled by Hunt Energy north of the Masson greenhouses in the early 1980's, provide insight into the nature of the deep reservoir. A fractured, composite Precambrian and Paleozoic carbonate reservoir is capped or confined by the Eocene Palm Park Formation aquitard. Laramide Orogeny compressional (Late Cretaceous to early Eocene) and Rio Grande rift extensional (Oligocene to present day) fault zones and fractures host the deep-seated reservoir in Precambrian and Paleozoic rocks (Seager and others, 1984; and Seager and others, 1986).

Temperature gradient information in the area indicates a broad area of 12.6 to $14.3^{\circ} \mathrm{F} / 100$ feet temperature gradients over the area from Hunt well 53-27 and southward to the Masson greenhouse facility (Witcher, unpub. data). These temperature gradients are likely to continue into the Palm Park aquitard cap to the top of fractured and possible karst Paleozoic carbonate units. The carbonate rocks were first encountered at 675 to 960 feet depth in the Hunt wells 25-34 and 53-27, respectively (files, New Mexico Bureau of Mines and Mineral Resources). A temperature log of well 53-27 shows that the well becomes isothermal below 1,000 feet at a temperature of about 185 ${ }^{\circ} \mathrm{F}$ (Witcher, unpub data). If the top of the deep reservoir is about 175 to 190 ${ }^{\circ} \mathrm{F}$ over a broad area, then the temperature gradients also broadly define the depth to the top of the reservoir between 600 and 1,000 feet depth, provided the Palm Park aquitard has no large lateral variations in thermal conductivity.

A north-northwest trending Quaternary normal fault delimits the western surface extent of the shallow rhyolite reservoir host at Radium 
Springs and the westward extent of the highest temperature gradients to the footwall side of the fault zone (Seager, 1975 and Witcher, unpub data). This fault crosses the eastern part of the Masson greenhouse complex.

The final site selected for drilling is on surface land owned by Masson that has an associated BLM geothermal lease that is held by Masson. This site is about 500 feet east of the northwest-striking fault zone on the foot wall and is situated in an area with no rhyolite outcrops. The selected site is closest to the fault zone, has the best access, and is just north of the greenhouse complex in an area with good security.

\subsection{Participants}

The Masson 36 production well project was administered by the Idaho Operations Office of the U. S. Department of Energy. The project was costshared by A. R. Masson, Inc. and the U. S. Department of Energy. The drilling contractor for the project, K. D. Huey Drilling of Capitan New Mexico, was selected on the basis of sealed competitive bid. Well site geotechnical services, permit coordination, and reporting was performed by Witcher and Associates of Las Cruces, New Mexico. The Resource Group, Palm Desert, California provided engineering assistance. Permitting and regulatory oversight was with the New Mexico State Engineer Office (NMSEO) and the BLM. 


\subsection{Permits}

All operations conformed to the regulations, permitting and operational procedures administered by the BLM and the NMSEO. All access and surface issues were closely coordinated with the BLM. All drilling was in compliance with federal Geothermal Resources Operational Orders (GROO's), directives of the BLM and NMSEO and stipulations of the permits. Prior to drilling, specific details were submitted to the BLM through a formal Plan of Operations Report, Application for Permit to Drill (APD) and Sundry Notices. As operator, A. R. Masson, Inc. posted the required bonds with the BLM. Daily and weekly communications with Federal and State regulators was maintained throughout the project.

\subsection{Scope}

This report on the Masson 36 geothermal production well details the drilling operations and provides a brief analysis of the drilling operation. The subsurface geology in the Masson 36 well is briefly discussed and interpreted and supporting well history detail and logs are provided in the Appendices. Recommendations for testing and monitoring are also presented. 


\subsection{DRILLING AND SITE OPERATIONS}

\subsection{Drill Site Layout}

The Masson 36 well is within the Radium Springs Known Geothermal Resource Area (KGRA) in the southeast quarter of the southwest quarter of section 3, Township 21 South, Range 1 West, approximately 2,380 feet from the west section line and 580 feet from the south section line at an approximate elevation of 3995 feet. The drill site is located on private surface, owned by Masson, adjacent a local arroyo flood control dike, trending east to west about 600 feet north of the Masson greenhouse complex. Access to the drill site is via a graded dirt road on the east side of the Masson greenhouse complex. A gate provides controlled entry to both the greenhouse operation and the well site. Gravel and caliche was laid down on the drill site road for all-weather egress to the drill site.

Dirt work included building a level and stable pad up to the grade of the top of the flood control dike. A couple of small dirt retention dams were placed along the backside of the flood control dike to act as temporary drilling fluid pits. The blowout prevention (BOPE) control or accumulater was installed east of the drill floor end of the rig. Overall layout provided for efficient water, mud, and equipment resupply, drilling operations, and well site geotechnical operations. An 8 by 8 by 8 feet reinforced cement cellar was constructed to allow clearance for BOPE equipment beneath the drill floor. 


\subsection{Water}

Water for drilling operations was obtained from a Masson greenhouse fresh water supply well located about a quarter of a mile from the drill site. A 3,500 gallon capacity water truck was used to transport water to the drill site from the Masson supply well. Two 400 barrel (20,000 gallon) frac tanks were kept full during the drilling operations. One frac tank was kept in reserve as a contingency for well control operations.

\subsection{Drill Rig Specifications}

A truck-mounted Mobile Equipment Service SR35 rig was used for constructing the Masson 36 well. The SR35 is a top drive rig that is equipped with a 1,350 cfm/350 psi Sullair air compressor. An auxillary 1,150 cfm/350 psi Ingersol Rand air compressor was also used in tandom with the rig compressor as needed. The SR35 utilizes hydraulic drives for the drill motors, pumps, and hoist, allowing excellent variable controls. The rig has a 110,000 pound pullback with the hoist, a rotary torque of 12,000 pounds, and a $700 \mathrm{hp}$ diesel engine on the deck.

\section{$2.4 \quad$ Well Control}

In the event that pressured fluids, gas, or rapidly boiling or flashing super-heated water entered the Masson 36 well while drilling, several steps were taken to insure that well discharges would be controlled. Well control consisted of blow out prevention (BOPE) equipment, valved flow and kill line ports, an auxiliary water tank with a minimum of 275 bbls (11,550 gallons) of water on site, and the monitoring of bottom-hole temperatures (BHT) and blooie line temperatures. The BOPE stack consisted of a Hydril GK 13 5/8 - 
$3 \mathrm{M}$ annular preventer installed on a $135 / 8$ inch well head spacer spool with flow and kill line ports. A rotating head was installed over the annular BOPE. The kill line port was connected to the auxiliary water tank via a pump. The BOPE was activated by a pneumatic accumulator and was function tested to 2,700 psi. The BOPE and casing was tested to 500 psi for 15 minutes with only 10 psi bleed off. The pressure tests were witnessed by Masson and BLM representatives.

\subsection{Hydrogen Sulfide Monitoring}

Industry-standard, continuous-monitoring, hydrogen sulfide detectors, equipped with automatic visual and audio alarms, were installed at suitable locations to include the drill rig operators console, the cellar on top of the BOPE, and at the flow or blooie line discharge. Alarms were set to trigger visual alarms at $10 \mathrm{ppm}$ hydrogen sulfide and audio alarms at $15 \mathrm{ppm}$. A wind sock was also installed at the location entry where it was visible to all site personnel. Self-contained breathing equipment were placed for emergency use at two different briefing area locations. The briefing areas were situated to provide one area that would be upwind of the hole at any given time. A warning and status sign was also placed at the entry to the drill site.

\subsection{Well Site Geology and Operations Monitoring}

Well site geotechnical operations included making field geologic logs of cuttings and archiving cuttings for future reference or study. Samples were taken at the blooie line over ten foot intervals. Cuttings will be sent for storage and archival at the New Mexico Bureau of Mines and Mineral Resources in Socorro, New Mexico. 
Geophysical and temperature logs completed the geotechnical operations. Several temperature logs were taken after overnight breaks in drilling in order to gain information on the temperature gradient and bottom hole conditions. Because cement is exothermic as it cures, an additional temperature log was obtained several hours after the surface casing was cemented. Determination of the cement top in the annulus, facilitated calculation of how much cement to order to fill the backside of the casing to the surface. Geophysical logs were run prior to running surface casing and after reaching total depth (TD), but prior to running the production casing string.

Operations monitoring included daily report log, daily cost tabulation, and a well history log. A summary of the daily report and well history log is listed in Appendix 1. The daily report log was used to document footage per shift, blooie temperature measurements, all drilling activities, and materials used in drilling. A well history log complemented the daily report log. The well history log was used to record chronologically important events at the well site such as visitors, drilling milestones, or any other events not recorded by daily report log.

\subsection{Drilling Summary and Analysis}

Drilling and casing depths in this report are referenced to the drill table (DF) at 4 feet elevation above the ground surface. All drilling was done with air foam, using either an air hammer above 672 feet depth or rotary tri-cone bit below 672 feet depth.

On the basis of a competitive bid, the Masson 36 drilling contract was awarded to K. D Huey Drilling a water well driller from Capitan, New Mexico in May 2000. The Huey drill rig did not move on to the site until August 2000 (Table 1 and Appendix 1). On 7 August the borehole was spudded. The 
drilling assembly included 17 1/2 inch stabilizers for a straight and guage hole along with the air hammer and bit. Drilling progressed smoothly until 9 August when the air hammer bit was shanked or in other words broken at the splines inside the air hammer and left at the bottom of the hole when the drill string was tripped or brought out of the hole. On 22 August the "fish" or air hammer bit was recovered. Options were discussed and geophysical logging was performed. It was decided to run and cement surface casing. On 28 and 29 August 465 (DF) feet of 13 3/8 inch surface casing was run in the hole. On 31 August, Dowell/Schlumberger arrived on site from Artesia, New Mexico and ran 144 bbls of cement (Appendix 4). Cementing across the ryholite zone was done in stages to insure that fractures and washout zones were sealed (Appendix 1 and 4). A temperature log ran several hours after Schlumberger demobilized showed the cement at the top of the rhyolite interval. A backside cement job by a local contractor was performed on 1 September to complete the cementing of the surface casing annulus to the surface. This additional 17 bbls of cements filled the hole and more with overflow at the surface. Between 2 and 16 September the drilling rig top drive was overhauled and the BOPE was installed and tested. Pressure testing was witnessed by the BLM and Masson's consultants on site. On 16 September drilling operations resumed with a 12 1/4 drilling assembly. It took an additional ten days to drill a $121 / 4$ inch hole to 800 feet and run and hang a 9 5/8 inch production casing string. A drilling assemblage change was necessary due to formation fluid production at 672 feet. The air hammer and bit was replaced with a tricone bit and rotary air operations resumed and the hole reached total depth (TD) of 800 feet on 22 September.

All operations from start to finish were daytime only and usually with only a two man crew. Analysis of drilling operations time indicates that only about 40 hours was actually spent drilling. A nearly equal amount of time or 37 hours was spent tripping in and out of the hole. Installing and uninstalling 
the BOPE took 47 hours. A much larger amount of time was spent repairing equipment or recovering a bit at the bottom of the hole. The bit splines broke in the air hammer while drilling the $171 / 2$ inch hole. However, the bulk of time between the contract award and the completion of the well involved waiting on drilling personnel, equipment and supplies.

\subsection{Well Completion}

A total depth of 800 feet was reached on 22 September 2000 within the Permian Hueco Formation, a mostly limestone unit with some interbedded shale. The Hueco Formation was an important drilling target. However, the hole only encountered 12 feet of this unit. Much greater production and possibly 10 to $15{ }^{\circ} \mathrm{F}$ higher temperatures are likely within this unit and underlying carbonate units at a few hundred feet greater depth. However, the well construction and completion provides a contingency for re-entering the hole at a later time in order to drill at least to $2,300 \mathrm{ft}$ depth if desired. 
Table 1 Daily Footage and Activity Log of the Masson 36 Well.

\begin{tabular}{|c|c|c|}
\hline date & $\begin{array}{l}\text { footage } \\
\text { feet/day }\end{array}$ & remarks \\
\hline $6 / 29$ & 24 & Auger conductor hole, run conductor casing and cement \\
\hline $6 / 30-8 / 6$ & 0 & Construct cellar and begin moving equipment on site \\
\hline $8 / 7$ & 120 & Finish rigging up, drill $171 / 2$ in surface hole with air hammer \\
\hline $8 / 8$ & 180 & Continue $171 / 2$ in surface hole with air hammer and foam \\
\hline $8 / 9$ & 150 & Ran temp log, continue $171 / 2$ in surface hole with air foam \\
\hline $8 / 10$ & 0 & Ran temp log, trip out, shanked bit in air hammer, bit fish on bottom \\
\hline $8 / 11-8 / 21$ & 0 & Attempt to recover fish \\
\hline $8 / 22$ & 0 & Ran BHT ( $\left.186^{\circ} \mathrm{F}\right)$, successfully recovered fish, decide to run casing \\
\hline $8 / 23$ & 0 & Ran geophysical logs \\
\hline $8 / 24-8 / 27$ & 0 & Casing delivered \\
\hline $8 / 28$ & 0 & Begin to run surface casing with shoe and float collar \\
\hline $8 / 29$ & 0 & Finish run of $461 \mathrm{ft} 133 / 8$ in surface casing, haul water \\
\hline $8 / 30$ & 0 & Haul water, prepare for cementers, rig maintenance \\
\hline $8 / 31$ & 0 & Cement surface casing, ran temp log to evaluate cement job \\
\hline $9 / 1$ & 0 & Top job cement backside and WOC \\
\hline $9 / 2-9 / 5$ & 0 & Repair rig top drive \\
\hline $9 / 6$ & 0 & Clean cellar, cut top surface casing, prepare to install BOPE \\
\hline $9 / 7-9 / 11$ & 0 & Continue repair of rig top drive \\
\hline $9 / 12$ & 0 & Ran temp log, installed rig top drive, wait on BOPE \\
\hline $9 / 13$ & 0 & Unload BOPE, installed well head flange and set spool with side ports \\
\hline $9 / 14$ & 0 & Nipple up annular, rotating head, accumulator and test, install $\mathrm{H}_{2} \mathrm{~S}$ monitor \\
\hline $9 / 15$ & 0 & Install kill and choke lines, install blooie line, make up drill tools \\
\hline $9 / 16$ & 51 & Trip in, tag cement at $423 \mathrm{ft}$, drill out cement and float collar, drill ahead \\
\hline $9 / 17$ & 0 & Repair auxiliary air compressor \\
\hline $9 / 18$ & 147 & Drill ahead using 12 1/4 in air hammer with foam \\
\hline $9 / 19$ & 0 & Trip out, wait on $121 / 4$ in tricone bit \\
\hline $9 / 20$ & 0 & Wait on $121 / 4$ in tricone bit \\
\hline $9 / 21$ & 68 & Make up drill tools, trip in, drill air rotary foam \\
\hline $9 / 22$ & 60 & Drill ahead, TD $800 \mathrm{ft}$, producing $1175 \mathrm{gpm} 196^{\circ} \mathrm{F}$ water while drilling air \\
\hline $9 / 23$ & 0 & Trip out, break down BOPE \\
\hline $9 / 24$ & 0 & Unload casing, run geophysical logs \\
\hline $9 / 25$ & 0 & Finish removing BOPE, prepare to run $95 / 8$ in production liner \\
\hline $9 / 26$ & 0 & Ran $95 / 8$ in production liner to $793 \mathrm{ft}$, turn off hanger, trip and laydown rig \\
\hline
\end{tabular}


Table $2 \quad$ Masson 36 Well Completion Specifications.

\begin{tabular}{llllllll}
\hline \hline item & $\begin{array}{l}\text { hole size } \\
\text { inches }\end{array}$ & $\begin{array}{l}\text { top } \\
\mathrm{ft}\end{array}$ & $\begin{array}{l}\text { bottom } \\
\mathrm{ft}\end{array}$ & $\begin{array}{l}\text { type } \\
\text { grade }\end{array}$ & $\begin{array}{l}\text { ID } \\
\text { inche } \\
\mathrm{s}\end{array}$ & $\begin{array}{l}\text { weight } \\
\mathrm{lbs} / \mathrm{ft}\end{array}$ & $\begin{array}{l}\text { cement } \\
\text { bbls }\end{array}$ \\
\hline conductor casing & 24 & surf & 28 & $\mathrm{H}-40$ & 20 & 78 & 3 \\
surface casing & $171 / 2$ & surf & 465 & $\mathrm{~N}-80 \mathrm{btc}$ & $133 / 8$ & 72 & 157 \\
production liner & $121 / 4$ & 395 & 793 & $\mathrm{~N}-80 \mathrm{btc}$ & $95 / 8$ & 47 & (hung) \\
production perf & $121 / 4$ & 562 & 793 & $3 / 8 \mathrm{rnd}$ & $95 / 8$ & $40 \mathrm{~h} / \mathrm{ft}$ & (punch)
\end{tabular}

\subsection{Geophysical and Temperature Logging}

The Masson 36 was geophysically logged several times before the well was completed. A suite of temperature logs was performed with the New Mexico State University (NMSU) temperature logging system (Table 3). Southwest Geophysical Services of Farmington, New Mexico was contracted to perform additional temperature logs and various other geophysical logs to include caliper, gamma, neutron and electric logs. The NMSU and Southwest Geophysical Services temperature logs were performed with wireline tools that were outfitted with thermister probes which have an accuracy of between 0.005 and $0.05{ }^{\circ} \mathrm{F}$. The geophysical and temperature logs are discussed in Chapter 3. 
Table 3 Geophysical and Temperature Logs of the Masson 36 Well.

\begin{tabular}{llll}
\hline \hline type log & date & $\begin{array}{l}\text { interval } \\
\mathrm{ft}\end{array}$ & logged by \\
\hline temperature & $8 / 9 / 2000$ & $0-265$ & NMSU \\
temperature & $8 / 10 / 2000$ & $0-425$ & NMSU \\
temperature & $8 / 21 / 2000$ & $\mathrm{BHT}$ & $\mathrm{NMSU}$ \\
temperature & $8 / 23 / 2000$ & $0-425$ & Southwest Geophysical \\
gamma/neutron & $8 / 23 / 2000$ & $0-425$ & Southwest Geophysical \\
caliper & $8 / 23 / 2000$ & $0-425$ & Southwest Geophysical \\
temperature & $8 / 31 / 2000$ & cement & NMSU \\
temperature & $9 / 12 / 2000$ & $0-430$ & NMSU \\
temperature & $9 / 24 / 2000$ & $0-789$ & Southwest Geophysical \\
gamma/neutron & $9 / 24 / 2000$ & $0-789$ & Southwest Geophysical \\
electric logs & $9 / 24 / 2000$ & $0-789$ & Southwest Geophysical \\
\hline
\end{tabular}

A caliper tool was run in the open hole prior to installing surface casing. The caliper log shows variation in borehole size which allows calculation of the amount of cement needed to insure a good surface casing seal. The gamma and neutron logs were also obtained. Maximum sampling radius for the gamma and neutron logs is about 1 to 2 feet into the formation. A logging rate of 20 feet per minute is used. As with temperature logs, the wireline signal is digitally converted into ASCII files for analysis and interpretation.

The gamma log measures gamma radiation from naturally occurring uranium, thorium, and potassium. Because different rock types have different radioactivity levels, the gamma log is a very useful lithology correlation tool. For instance, shales and clay may have higher natural radioactivity than sandstone and sand. The neutron tool contains an active radioactive source 
that emits neutrons and a detector that spaced on the tool about two feet from the neutron source. Neutrons emitted by the tool are principally slowed to low energies by hydrogen (ie. water and hydrocarbons) in the formation, resulting in less signal for the detector if porosity is high. Where hydrogen content is low (low porosity) the neutrons diffuse much greater distances (closer to the detector) before slowing to low energies. Because of hydrogen sensitivity, the neutron log has use as an indicator of relative formation porosity.

Electric logs can also measure the amount of porosity. Because salty water is a good conductor of electricity compared to rock or drilling mud, electric logs can have much value in well evaluation. The electric logs measure voltage potential and they are reported as a difference as in the SP log or resistance as in the single point "resistance" log or as resistance per unit length as in the normal (long 64 inch - short 16 inch) "resistivity" logs.

\subsection{Site Cleanup}

Site cleanup of the Masson 36 well pad at the end of well completion consisted of removing all trash and any oil contaminated soil to approved disposal sites. All equipment was removed from the site, except for the well head and locked well head housing. The cement cellar used for the BOPE was back filled to pad level to prevent animals and people from accidental injury. 


\subsection{GEOLOGY AND GEOTHERMAL RESOURCE}

\subsection{Geology of Masson 36 Well}

A summary geologic log of the Masson 36 well is found in Appendix 2. Figures 2, 3 and 4 provide graphic logs of lithology and the geophysical logs for the well. Two productive geothermal reservoirs were encountered while drilling Masson 36. Each reservoir produced over 1,000 gpm while drilling with air.

The uppermost production zone, between 120 and 222 feet depth occurred in a fractured rhyolite with drilling discharge temperature around 151 ${ }^{\circ} \mathrm{F}$. This upper reservoir was sealed off with the surface casing string and cement. Figure 1 shows this zone with a relative high gamma (125 to 150 API) and caliper log deviations much greater than the 17 1/2 inch nominal bit diameter. The 102 feet thick rhyolite intrusion is believed to be the same unit that provides current production at Radium Springs in the nearby shallow Masson wells. Rhyolite is exposed at the surface about 1,000 feet south and southeast of the Masson 36 well site. If this correlation is correct, then the rhyolite represents a dike that dips at low angle to the north or north-northeast and discordantly intrudes across the clay-rich "andesitic" Palm Park aquitard. The Palm Park forms a confining boundary on the shallow rhyolite geothermal reservoir except where it intersects the surface and shallow alluvial aquifer south of the drill site.

At the surface, the Palm Park Formation is a mostly andesitic lahar (hot volcanic mudflow deposit) breccia with an altered muddy and clay-rich matrix. Alteration is variably intense and ranges in color from purple to blue green. Clay, chlorite, and epidote are important alteration phases. Judging from cuttings and geophysical logs, the Palm Park in the Masson 36 well is 


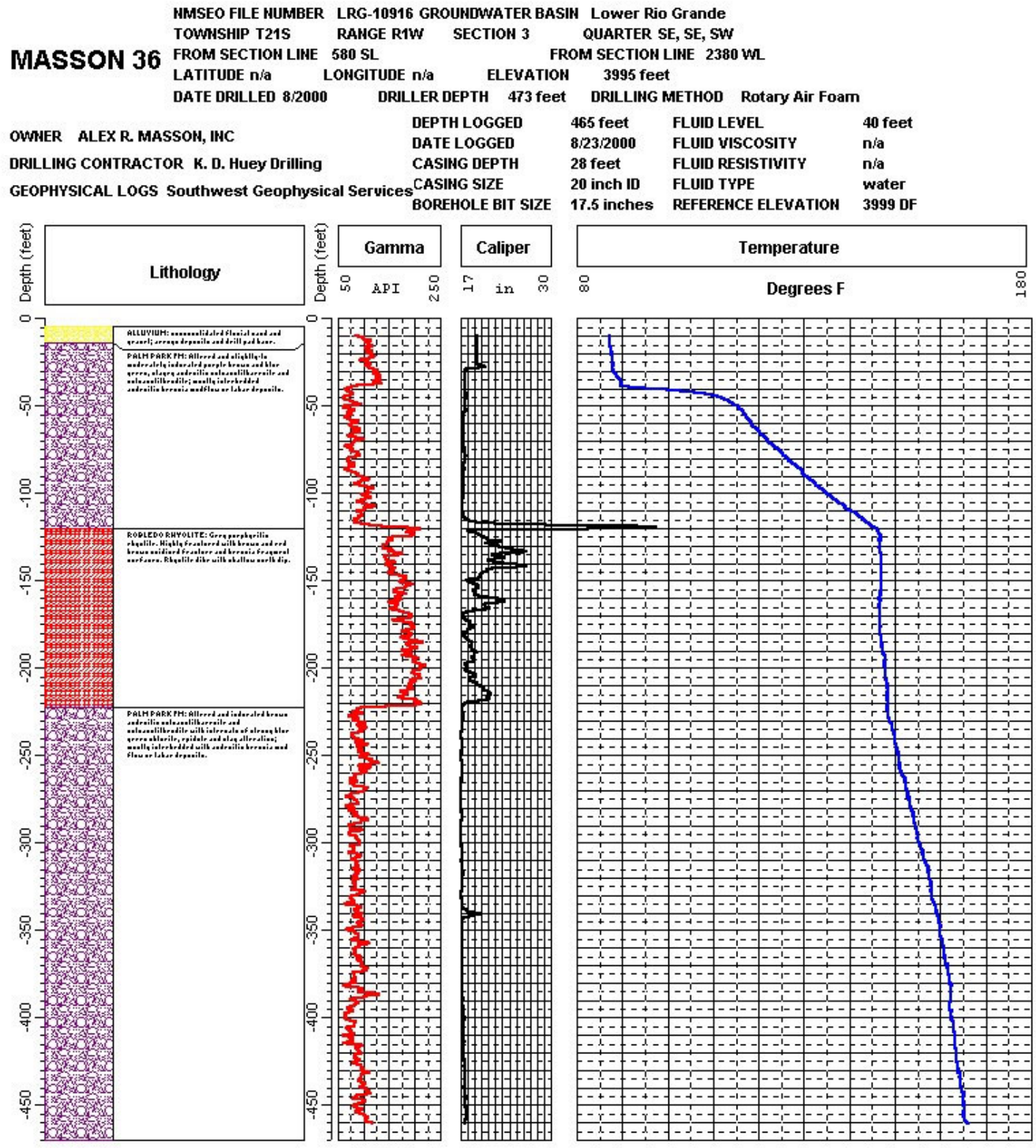

Figure 2. Pre-Surface Casing Temperature and Geophysical Logs. 


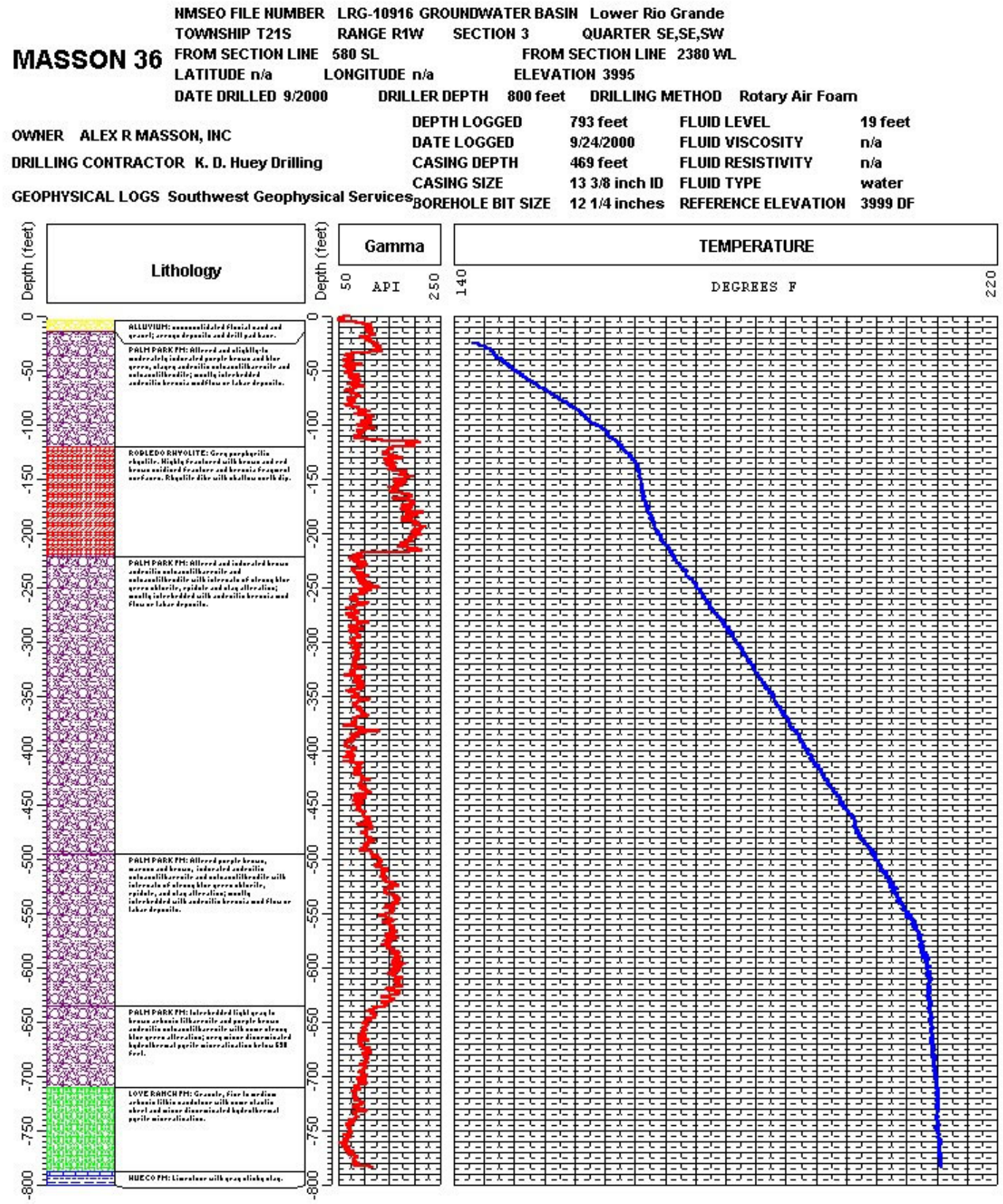

Figure 3. Post-Drilling Gamma and Temperature Logs. 


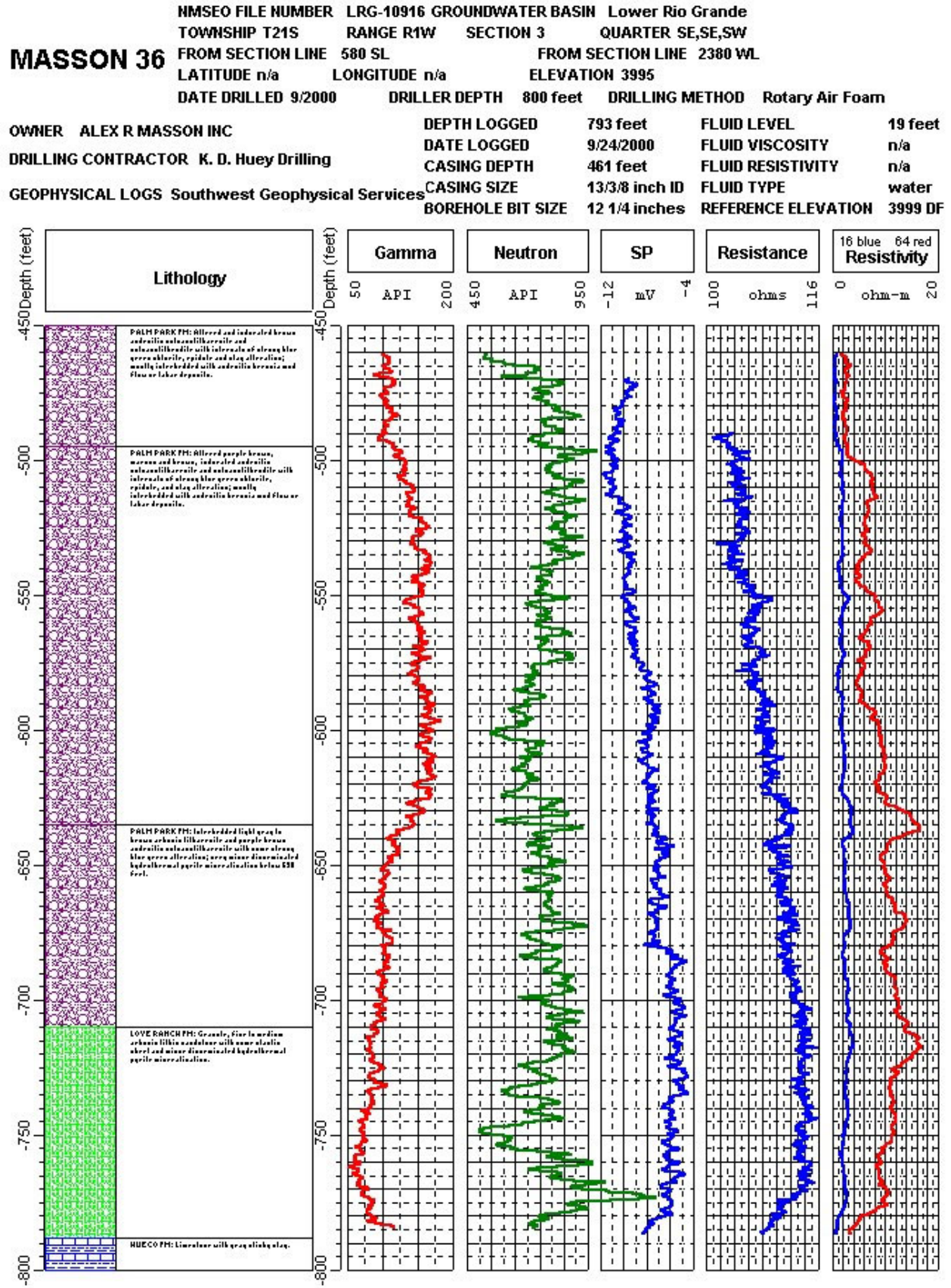

Figure 4. Electric Logs of the 460 to 793 Feet Interval 
consistent with surface outcrops to at least a depth of 495 feet. Very little water production was noted in the Palm Park either prior to drilling into the rhyolite at 120 feet or after drilling out of the surface casing cement until at least 556 feet depth.

Between 495 and 635 feet depth the Palm Park is interbedded with abundant indurated lithic sandstone that is either purple brown and dark maroon or blue green color. Overall, this andesite volcanoarenite unit of the Palm Park is less clay-rich and may contain some fracture permeability. The first notable water production occurred at 556 feet depth and probably represents the top of the deep fracture-dominated reservoir. The first major production occurred at 600 to 615 feet depth at which point the blooie line discharge increased dramatically and the flow turned orange red and light reddish brown. It is believed that an important fracture was drilled in this interval. An additional fracture zone is inferred from reddish discharges at about 630 feet depth.

From 635 feet to 710 feet depth the Palm Park again changes character. This unit is an interbedded light gray to brown arkosic lithic sandstone and purple and blue green andesite volcanoarenite. Below 690 feet depth some disseminated pyrite was noted in cuttings. Again, several fractures were encountered in this zone, judging from periodic and temporary reddish orange discharges at the blooie line. The basal Palm Park unit appears to be a transitional unit with the underlying Love Ranch (?) Formation.

From 710 to 788 feet depth, cuttings are granule, fine to medium arkosic sand with some clastic chert and disseminated hydrothermal pyrite. This unit is tentatively correlated with the Eocene Love Ranch Formation (Mack and others, 1998). Several important fracture zones occur in this unit. The most important fractures occur between 730 and 765 feet depth. It may be notable that while temperature logging, the temperature probe temporarily 
hung at 752 feet depth. Turbulent flow in the bore around a fracture zone could have caused the probe to deviate from vertical and intersect the borehole wall as the probe was lowered. Also, the low neutron log response at this interval also gives support to a major fracture zone in this interval.

At 788 feet depth, limestone chips were discharged at the blooie line. At the end of temperature logging, the wire housing around the thermister was clogged with light gray, sticky clay. This clay probably come from 793 feet, total logging depth, and may represent a clay bed in the limestone unit that swelled across the hole so that the probe was unable to reach the TD of 800 feet. An X-ray diffraction analysis of the clay shows that it is montmorillonite, a swelling clay (Appendix 3 ). The clay and limestone are believed to represent the Permian Hueco limestone.

Water levels encountered at various stages of drilling of the Masson 36 well provide some insight into the hydrogeology of the site. While drilling in the Palm Park Formation above the rhyolite, the first notable indication of water was observed at 55 feet depth. After the shallow rhyolite reservoir was drilled, a water level of 40 feet was noted in temperature and geophysical logging. When the hole reached TD at 800 feet depth, with the upper rhyolite reservoir was sealed off by a cemented surface casing, the water level in Masson 36 was about 19 feet depth. A positive upward head difference at least of 21 to 36 feet exists between the shallow thermal and cold water and the top of the deep reservoir at Radium Springs.

\subsection{Thermal Regime of the Masson 36 Well}

Several temperature logs were run in the Masson 36 well during the drilling operations in order to gain subsurface information on hydrogeologic conditions, temperature gradients, and to evaluate the overall integrity and 
the top of the cement in the annulus between the casing and formation after the initial surface casing cement job by Dowell Schlumberger.

The last temperature log prior to running the production casing gives the best information on potential production temperatures and overall thermal regime (Figure 3). From 560 feet to 793 feet the borehole shows very low temperature gradients or almost isothermal conditions. This is expected in a fractured reservoir due to upflow in the formation. The temperature of this zone is about 209 to $212{ }^{\circ} \mathrm{F}$ and should closely reflect the production temperatures when the hole is pumped for production. Between 560 and 220 feet depth, the borehole shows a steep gradient that is largely the result of conductive processes in the country rock beyond the borehole. Conductive heat transfer processes are dominant only where no or extremely low natural flows of water occur. While the gradient in this interval shows a slight upward convex profile that could indicate some upward seepage across the Palm Park aquitard, the curvature may simply represent disturbance from convection in the large diameter borehole or slightly increasing thermal conductivity in the Palm Park unit with depth. Overall, the temperature gradient supports other data that indicate the deep reservoir is confined by a relatively impermeable Palm Park Formation. Of interest also is the interval from 120 to 220 feet. Here, the temperature gradient becomes isothermal once again. This interval coincides with the shallow rhyolite reservoir.

Figure 5 is a plot of all of the temperature measurements taken in the Masson 36 well, except for the cement temperature log. These logs plot to the left of the final log and show much cooling due to drilling disturbance. However, note that discrete bottom hole temperatures (BHT) for each log are 


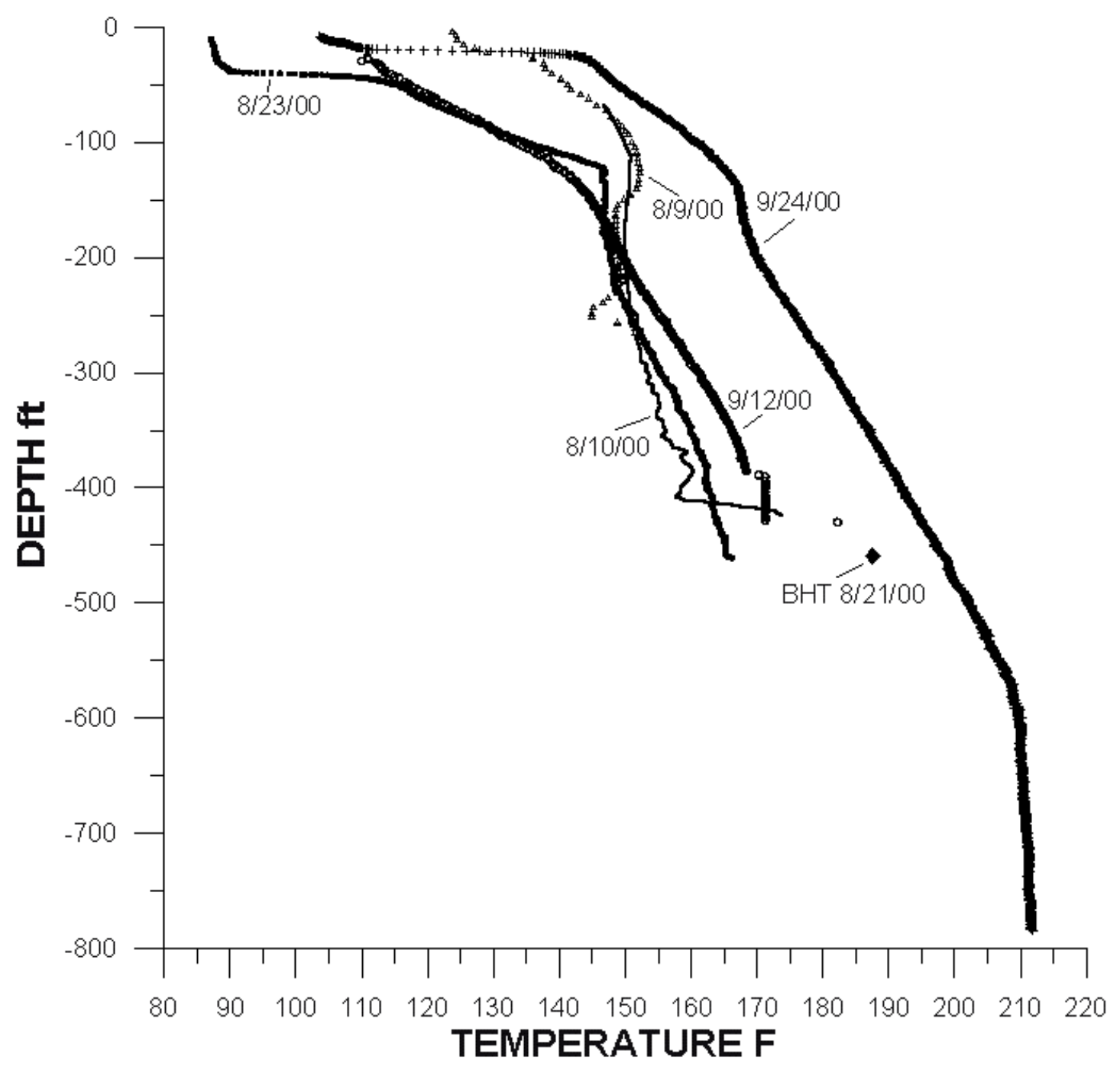

Figure 5. Composite Graph of Temperature Logs and BHT Measurements. 
all much higher than measurements taken above them. The BHT measurements are the least disturbed by drilling because cooler drill water and air has only circulated past the newly drilled or uncovered rock for a comparatively short time. The BHT's were used during the drilling to qualitatively estimate reservoir tops and temperatures.

\subsection{Reservoir Chemistry}

After reaching total depth at $800 \mathrm{ft}$, the well was blown with air, but without foam additives, for two hours to clean the bore and also to obtain flow rate information and to acquire a good sample for water chemistry. An unfiltered sample with no acid preservatives was collected and delivered to the SWAT lab at NMSU for chemical analysis. A report of analysis is included in Appendix 3. The produced fluid is a sodium chloride water with a TDS of $3,800 \mathrm{mg} / \mathrm{L}$. Silica $(\mathrm{Si})$ concentration, if recalculated as $\left(\mathrm{SiO}_{2}\right)$, is $67 \mathrm{mg} / \mathrm{L}$ and gives a quartz geothermometer reservoir temperature of $240{ }^{\circ} \mathrm{F}$ (Fournier and Rowe, 1966) The chalcedony geothermometer is $189^{\circ} \mathrm{F}$. Temperature of the discharge at the time of collection was $196{ }^{\circ} \mathrm{F}$ as measured with a laboratory mercury thermometer. The maximum temperature of the deep reservoir at Radium Springs may not exceed $240^{\circ} \mathrm{F}$.

At the end of drilling and air stimulated flow testing, a powdery light pink scale was noted at the end of the blooie line. It is more than likely that most of this scale formed during the flow test at the end of drilling because cuttings would no doubt have eroded any soft scale formation. The scale only formed on the last few feet of the blooie line. An X-ray diffraction analysis of the scale powder reveals that it is a mixture of calcite and aragonite (see Appendix 3). The amount of scale is minor and probably resulted from loss of dissolved carbon dioxide at the blooie line discharge. 


\subsection{CONCLUSIONS AND RECOMMENDATIONS}

The Masson 36 well is completed in the top of a deep confined reservoir at Radium Springs. Production temperatures of 210 to $212^{\circ} \mathrm{F}$ are likely. It is believed that the well will sustain long-term production in excess of 1,500 to $2,000 \mathrm{gpm}$.

A long term flow test should be performed to determine production and final pump design. The pump test should begin as a step test and end with a steady-state drawdown test for at least 48 hours. As important as measuring drawdown in Masson 36, drawdown should also be measured in several of the current shallow production wells. Drawdown should also be observed in at least one of the cold wells. Ideally, drawdown should also be monitored in the Hunt 25-37 well while the pump test is conducted. This will require BLM approval. If step tests indicate it is possible, Masson 36 should be pumped at $3,000 \mathrm{gpm}$ for the steady-state drawdown test in order to stress the reservoir and determine any hydraulic connection with shallower reservoirs or with the deep reservoir to the north where the Hunt wells were drilled. The test should be planned and managed by a qualified engineer or geologist and not by a local southern New Mexico water well driller.

This well is configured in such a way that a very large pump can be installed. Also, the well could be deepened several thousand feet in the future if higher temperature or additional production is desired for either the greenhouse or for small-scale binary electrical power generation or both.

It is also recommended that Masson undertake a disciplined and regular monitoring of selected wells including the Masson 36 well. This would include chemistry, temperature, and water level measurements taken at regular and periodic times. As a part of such an effort, all of the wells to be monitored should be surveyed so that a precise elevation is known. If any shallow production or injection wells are to be abandoned, I would also 
recommend modifying the well constructions to create dedicated monitor wells or piezometers rather than plugging and abandoning the wells. This would require BLM and or NMSEO approval; but, I believe the agencies would be supportive of a proper monitor well design and use plan.

Without a monitoring program, the reservoir will probably not be understood. Monitoring also provides baseline data and procedure that can provide a measure of foresight into reservoir behavior and also "early warning" of impacts from possible overly aggressive development of electric power on the Radium Springs KGRA immediately north of the greenhouse. 


\subsection{REFERENCES}

Fournier, R. O., and Rowe, J. J., 1966, Estimation of underground temperatures from the silica content of water from hot springs and wet-steam wells: American Journal of Science, v. 264, p. 685-697.

Gross, J, 1986, Results of ground water monitoring and pump testing in the Radium Springs geothermal area, New Mexico: Malcolm Pirnie, Inc. Phoenix, Arizona, report prepared for the New Mexico State Engineer's Office and A. R. Masson, Inc., 41 p.

Mack, G. H., Kottlowski, F. E., and Seager, W. R., 1998, The stratigraphy of south-central New Mexico, in Mack, G. H., Austin, G. S., and Barker, J. M., eds., Las Cruces Country II: New Mexico Geological Society 49th Field Conference Guidebook, p. 135-154.

Reiter, M., Barroll, M. W., and Minier, J., 1991, An overview of heat flow in southwestern United States and northern Chihuahua, Mexico, in Slemmons, D. B., Engdahl, E. R., Zoback, M. D., and Blackwell, D. D., eds., Neotectonics of North America: Geological Society of America Decade of North American Geology Map Volume 1, p. 457-466.

Ross, H. P., and Witcher, J. C., 1998, Self-potential surveys of three geothermal areas on the southern Rio Grande rift, New Mexico, in Mack, G. H., Austin, G. S., and Barker, J. M., eds., Las Cruces Country II: New Mexico Geological Society 49th Field Conference Guidebook, p. 93-100.

Seager, W. R., 1975, Geologic map and sections of south half San Diego Mountain quadrangle, New Mexico: New Mexico Bureau of Mines and Mineral Resources Geologic Map 35, 1:24,000 scale. 
Seager, W. R., and Morgan, P., 1979, Rio Grande rift in southern New Mexico, West Texas, and northern Chihuahua, in Riecker, R. E., ed., Rio Grande Rift: Tectonics and Magmatism: American Geophysical Union, Washington, D. C. p. 87-106.

Seager, W. R., Mack, G. H., Raimonde, M. S., and Ryan, R. G., 1986, Laramide basement-cored uplift and basins in south-central New Mexico, in Clemons, R. E., King. W. E., and Mack, G. H., eds., Truth or Consequences Region: New Mexico Geological Society 37th Annual Field Conference Guidebook, p. 120-130.

Seager, W. R., Shafiqullah, M., Hawley, J. W., and Marvin, R. F., 1984, New $\mathrm{K}-\mathrm{Ar}$ dates from basalts and the evolution of the southern Rio Grande rift: Geological Society of America Bulletin, v. 95, p. 87-99.

White, D. E., and Williams, D. L., 1975, Assessment of geothermal resources of the United States - 1975: U. S. Geological Survey Circular 726, 155 p.

Witcher, J. C., 1988, Geothermal resources in southwestern New Mexico and southeastern Arizona, in Mack, G. H., Lawton, T. F., and Lucas, S. G., eds., Cretaceous and Laramide Tectonic Evolution of Southwestern New Mexico: New Mexico Geological Society 39th Annual Field Conference Guidebook, p. 191-197. 

APPENDIX 1

SUMMARY WELL HISTORY OF THE MASSON 36 WELL 


\section{Well History \\ Compiler: Bill Rickard,Resource Group \\ Well Name: Masson 36}

Operator: Alex R. Masson, Inc.

Spud Date: 07-Aug-00
Field: Radium Springs, NM

Completion date: $26-$ Sep-00

Range: 1 West

Location:580' North and 2386.0' East of the Southwest corner of Section 3, Dona Ana County, New Mexico.

29-Jun-00 Depth: 24

Set 20" conductor at 24.2' below ground level.

30-Jun-00 to 06-Aug-00 Depth:24

No drilling activity. Moved in and rigged up rig and associated equipment.

07-Aug-00 Depth: 143

Made up bottom hole assembly. Installed pack off assembly on conductor and installed blooie line. Cleaned out cement in bottom of conductor and drilled 17-1/2" hole from 23' to 83' with air/mist, reamed each single down and circulated hole clean. Encountered first water at about 70'. Serviced rig. Drilled 17-1/2" hole from $83^{\prime}$ to $143^{\prime}$ with air/mist. Encountered rhyolite and hot water at 123 . Blooie line temperature increased to $150 \mathrm{~F}$, with an initial water flow of about $200 \mathrm{gpm}$. rhyolite very fractured. Torque and drag increased significantly. Reamed and circulated hole every $1^{\prime}$ to 2 '. Reamed single down and circulated hole clean. Had 400-500 gpm flow at end of day. No fill. Shut down for night. Repaired hydraulic leak.

\section{8-Aug-00 Depth: 323}

Serviced rig. Had less than 1' of fill on bottom. Drilled 17-1/2" hole from $143^{\prime}$ to 323 ' with air/mist, Reamed each single down and circulated hole clean. Had tight hole and very high torque $164 '$ - 165'. Re-entered andesite at 220'. Water flow increased from about $400 \mathrm{gpm}$ to $600-800 \mathrm{gpm}$ at end of day. Circulated hole clean $\&$ shut down for night. 
09-Aug-00 Depth: 473

Serviced Rig. Ran temperature log inside of drill pipe to top of bottom hole assembly at 268'. Temperature survey showed maximum temperature of $151 \mathrm{~F}$ at the top of the fractured rhyolite. (Had rhyolite from 123' to 220'.) Temperature dropped to $145 \mathrm{~F}$ at 250', in the andesite. Had no fill on bottom. Drilled 17-1/2" hole from 323' to $443^{\prime}$ with air/foam, reamed each single down. Had about $600 \mathrm{gpm}$ water flow to surface. Cuttings returns to surface decreased and had some minor fill on connections. Added polymer to injectate and circulated hole clean. Drilled some tuff with the andesite just above 400'. Drilled 17-1/2" hole from 443' to 473' with air/foam, had high torque and had to pick up frequently. Circulated hole clean with stiff foam and reamed single down. Shut down for night. Had up to $40 \%$ serpentine in andesite. Hammer not operating properly without lots

of soap.

10-Aug-00 Depth:473

Serviced rig. Ran temperature survey inside of drill pipe to 420', maximum temperature $174 \mathrm{~F}$ at 420'. Maximum temperature gradient 15F/100', Maximum expected temperature at casing point is $204 \mathrm{~F}$. Rigged up to pull out of hole, worked on rig tongs. Circulated and singled out of hole, circulated each single out to 203. Singled out to top of tools. Pumped out cellar and removed pack off assembly. Pulled tools, left bit in hole. Shank broke off bit leaving part of the spline in the air hammer. Fish left in the hole consists of the bit and about 5 " of shank up for a fishing neck. Broke out tools and removed 17-1/2" stabilizer from air hammer. Attempted to break out air hammer to recover remaining spline with out success. Shut down for night.

21-Aug-00 Depth: 473

Engaged fish with screw on sub on second attempt. (Previous attempts to engage the fish with screw on sub and taper tap the previous week had been unsuccessful in recovering the fish.) $\mathrm{POH}$ to tools and shut down for night.

22-Aug-00 Depth: 473

Serviced rig and removed pack off assembly. Pulled tools and recovered 17-1/2" hammer bit. Laid down fish and fishing tools. Ran 17-1/2" stabilizer in hole. Ran temperature survey in open hole. Maximum BHT was $186 \mathrm{~F}$ at $473^{\prime}$. Discussed options with BLM, geologist and driller. Decided to run casing at this depth. 
Laid down 17-1/2" tools. Prepared for loggers. Shut down for night.

23-Aug-00 Depth: 473

Rigged up SouthWest Geophysical loggers. Ran temperature log from surface to 466'. BHT was $169 \mathrm{~F}$ at 466'. Ran 3 arm caliper. Tool failed. $\mathrm{POH}$, replaced tool and reran 3 arm caliper. Logged from 465' to surface. Had washout, through rhyolite, of 19 "avg. from 220' to $145^{\prime}$ and of 23" avg., to $115^{\prime}$ ', remainder of hole gage is okay. Ran Gamma Ray. Logged from 465' to surface. Rhyolite was well delineated from 220' to $120^{\prime}$. Rigged down loggers. Released loggers and shut down rig.

24-Aug-00 to 27-Aug-00 Depth:473

No drilling activity. Waited on casing delivery form Houston.

28-Aug-00 Depth: 473

Casing arrived on location over weekend. Serviced rig. Rigged up to run casing. Ran shoe joint with float shoe tacked and centralizer 10' up from shoe. Worked on rig tongs. Installed float collar and shut down for night.

29-Aug-00 Depth: 473

Ran 13-3/8", 72\#, N-80, Butt. casing. Installed float between first and second joints. Tacked all connections on first three joints. Ran centralizers above float shoe and float collar and on collar of second joint. Ran centralizers on every other collar to $60^{\prime}$ below table. Joints \# 6 \& 7 ran tight and joint \#11 hit an obstruction and fell through. String consists of float shoe, 1 joint casing, float collar and 13 joints casing, total length equals 461.12', with casing shoe at 460.12'. Rigged down casing running tools. Hauled water for cement job. Shut down for night.

30-Aug-00 Depth: 473

Hauled water and prepared for cement job. Removed top drive to repair hydraulic oil leak. Waited on Dowell. Worked on top drive. Top drive will be completely gone through to replace all seals and broken parts. Dowell will be on location at 10 AM tomorrow.

31-Aug-00 Depth: 473

Waited for Dowell Schlumberger to arrive on location. Rigged up to cement. Rigged up Dowell to cement 13 3/8" casing shoe at $461.42 \mathrm{ft}$, and float collar at 429.72'. Pressure tested cementing lines to 1000 psi before cementing operations. Pumped 77 barrels of water ahead, followed by 78 barrels of lead cement 
consisting of 225 sacks "H" cement with 40\% D66, 3\% D29 and $2 \%$ D20 mixed at $14.5 \mathrm{ppg}$ and 62 barrels of tail slurry consisting of 250 sacks "H" cement with $40 \%$ D66, 2\% D65 and $0.2 \%$ D46 mixed at $16.4 \mathrm{ppg}$. Dropped wiper plug, displaced with 64 barrels of displacement fluid (water) at $8.3 \mathrm{ppg}$. Pumped final displacement in three stages waiting 10 minutes between stages. Bumped plug with 700 psi. Bled off pressure to zero, floats held. CIP at $1358 \mathrm{Hrs}$. WOC. Ran temperature survey at one meter intervals from surface to top of float collar at $1800 \mathrm{Hrs}$. Temperature survey indicated top of cement in 17$1 / 2$ " hole at 120 '. Top of cement correlates to electric log top of lost circulation zone.

01-Sep-00 Depth: 473

Met with Masson site supervisor and ordered 5 1/2 cubic yards of Redi-mix concrete, light slurry, suitable for filling of $133 / 8$ " X $20 "$ annulus. Rigged up Redi-mix truck to well annulus. Poured two cubic yards of concrete into well annulus and had water returns to surface. Continued pouring slurry into annulus until approximately 3.5 cubic yards was placed in annulus, perfect fill in the annulus calculated at 3.6 cubic yards. Measured top of cement in $133 / 8$ " X 20" annulus using a 10 foot measuring stick. Had continuous returns to surface of water from two cubic yards placed until the total 3.5 cubic yards of concrete was placed. At conclusion of cement placement the fluid stood level at the flow nipple. WOC.

02-Sep-00 to 05-Sep-00 Depth:473

No drilling activity. Waited on repairs to top drive.

06-Sep-00 Depth: 473

Cleaned out mud from bottom of cellar, cleaned out timbers and all debris. Cut 20" casing in two pieces 18" up from cellar floor. Chipped away cement around $133 / 8$ " casing. Cut off $133 / 8$ " casing 18" up from cellar floor. Left $133 / 8$ " and 20 " casing stub on wellhead until installation of BOP equipment.

07-Sep-00 to 11-Sep-00 Depth:473

No drilling activity. Waited on repairs to top drive.

12-Sep-00 Depth: 473

Installed top drive, tested same by rotating. Nippled down 13 $3 / 8$ " and 20" casing stubs and removed same from cellar. Built up 12-1/4" stabilizers to gauge. Ran temperature survey from 
$429 \mathrm{ft}$ to surface. Maximum temperature recorded at 429 feet was 181 degrees $F$.

13-Sep-00 Depth: 473

Unloaded BOP equipment from delivery truck. Set accumulator in front of rig. Cut off and beveled 13-3/8" casing to receive wellhead flange. Set $13-5 / 8 "-3 \mathrm{M}$ wellhead flange in place and leveled same. Welded wellhead flange to $133 / 8$ " casing. Set $13-5 / 8$ "-3M spacer spool with side outlets on top of wellhead flange and nippled up spacer spool.

14-Sep-00 Depth: 473

Set Hydril (GK 13-5/8-3M) on top of spacer spool, nippled up Hydril to stack. Set "Williams" rotating head on top of Hydril, nippled up rotating head to stack. Installed hydraulic lines from Hydril to accumulator. Function tested Hydril with accumulator pressure at 2700 psi. Installed H2S safety equipment as per drilling program. Installed three $\mathrm{H} 2 \mathrm{~S}$ monitors, one at top of BOPE, one at drillers console, and one at exit of flow line. H2S monitors set to activate light at $10 \mathrm{ppm}$, alarm siren sounds at $15 \mathrm{ppm}$. Function tested H2S monitors OK. Set two each wind socks, one located at pipe trailer next to rig and one located at Baker tank next to rig. Set two briefing area signs on location. Set entry flag at bottom of hill leading to location. Set green flag at entry indicating no H2S. Continued to nipple up BOPE stack, tightened bolts on stack several times. Ran joint of drill pipe into Hydril, closed bag and pressure tested BOPE and casing to 500 psi for 15 minutes. Checked BOPE stack visually, had no leaks. Had only 10 psi bleed off during the 15 minute test. BOPE tested in compliance with contract, witnessed by BLM and A. R. Masson representative.

15-Sep-00 Depth: 473

Rigged up kill and choke lines to spacer spool. Rigged up blooie line to well site sump, welded supports to blooie line. Installed thermo-well in blooie line. Picked up drilling tools, found piston in air hammer jammed, laid down air hammer and attempted to free piston with lubricant.

16-Sep-00 Depth: 525

Rigged up drilling tools with 12-1/4" air hammer, ran in hole with drilling tools and made up drill string. Stood back drilling tool string. Picked up rotating head rubber stabbing tool on 5" drill pipe. Stabbed through rotating head rubber, stood back drill 
pipe and rotating head assembly in derrick. Ran in hole with drilling tool string, made up 5" DP to tool string and set rotating head assembly into rotating head body. Made up locking nut on rotating head. Rigged up check valve on kill line. Ran in hole with 5" drill pipe and tools to top of cement at 423 '. Circulated water out of hole with air and foam. Drilled with one air compressor. Drilled cement, float collar, cement, and float shoe. Drilled 12-1/4" hole in new formation from 469' to 525'. Shut down for night, secured well.

17-Sep-00 Depth: 525

Auxiliary air compressor fuel controller broken. No drilling for 24 hr period. Drilling contractor obtaining replacement parts.

18-Sep-00 Depth: 672

Repaired auxiliary air compressor. Circulated hole clean with two air compressors at $525^{\prime}$. Drilled 12-1/4" hole to 555'. Flow line temperature $103 \mathrm{~F}$. Drilled 12-1/4" hole from 555' to 615'. Flow line temperature $168 \mathrm{~F}$. At 610' Had formation change, returns looked smokey brown. Began small flow of water at 610'. Connection at $615^{\prime}$ took 3 minutes to unload water from wellbore. Drilled 12-1/4" hole from 615' to 645', flow line temperature increased steadily to $172 \mathrm{~F}$. Drilled 12-1/4" hole from 645' to 660', had formation change, returns turned bright red and orange in color, water flow at blooie line increased steadily. Flow line temperature $185 \mathrm{~F}$. Drilled 12-1/4" hole from 660 ' to 672 ', penetration rate decreased to near zero, Due to back pressure on drill string. Flow line temperature at $203 \mathrm{~F}$. Decision made by drilling contractor to pull out of hole and make up tri-cone bit. Estimated water flow between 500-700 GPM. Shut down for night at $1815 \mathrm{Hrs}$.

19-Sep-00 Depth: 672

Pulled out of hole with drill string, recovered all tools. Wait on arrival of tri-cone bit. 
21-Sep-00 Depth: 740

Broke out air hammer. Made up new bottom hole assembly, (assembly \#2), identical to bottom hole assembly \#1 with the addition of a float sub and a 12-1/4" bit instead of the air hammer. Ran in hole with new bottom hole assembly to 672'. Circulated hole, FLT $=203$ F. Drilled 12-1/4" hole to 707', experienced increase in water flow at blooie line. Drilled kelly down at 710', had show of pyrite in cuttings. Drilled 12-1/4" hole from 710 ' to 740 '.

22-Sep-00 Depth: 800

Rigged up 36 " X 12" square weir to measure well flow. Tested well flow with the aid of air compressors with total depth at 740'. Well flow measured at weir, with weir depth of 4", is 845 GPM. Measured flow line temperature of $190 \mathrm{~F}$ with hand held temperature meter of KD Huey Drilling Co. Took water samples from flow line at 740' depth. Received orders to deepen well to 800'. Drilled 12-1/4" hole from 740 ' to 765 ', had drilling break at 765'. Water flow at weir increased after drilling break from 845 GPM to 1175 GPM. Measured flow line temperature after drilling break of 197 F. Drilled 12-1/4" hole from 765' to 800' total depth. Shut down air compressors and flow ceased, welded thermowell into blooie line to measure flow line temperature. Flowed well with the aid of air compressors, flow line temperature of 91 C (196 F). Measured flow at weir of 1175 GPM. Shut down for night.

23-Sep-00 Depth: 800

Pull out of hole with drilling assembly. Recovered all of drilling assembly. Rigged down BOPE stack, removed rotating head. Unbolted Hydril and spacer spool.

24-Sep-00 Depth:800

Unloaded 15 joints of 9-5/8", 47 \#/ft, N-80, buttress thread casing ( 8 joints of casing blank, 7 joints perforated). Unloaded 13-3/8" X 9-5/8" liner adapter, 9-5/8" casing shoe, and 9-5/8" liner setting tool. Rigged up to run electric logs, calibrated temperature tool. Ran in hole with temperature tool, hung up at $756 \mathrm{ft}$, spaded through obstruction, ran in to total depth of 793'. Logged out of hole with temperature tool, maximum recorded temperature was $212 \mathrm{~F}$ at bottom of logged interval. Temperature log indicates fluid level in wellbore at 20'. Rigged up Gamma Ray/Neutron logging tool. Ran in hole with GR/N tool to total depth of $791 \mathrm{ft}$, logged out of hole. 
Gamma Ray tool indicates bottom of 13-3/8" casing at 461'. Re-ran Gamma Ray/Neutron log, first run did not record Neutron log. Logged out of hole with GR/N log from 793'. Fluid level indicated at 20'. Ran in hole with Resistivity/SP tool to 793'. Logged out of hole with resistivity/SP tool to inside 13-3/8" casing. Rigged up 3 armed caliper tool, tool did not function, ran second 3 armed caliper tool to $793 \mathrm{ft}$, spooling motor slipped chain, hand pulled caliper tool from well. Decision made to not run caliper tool. Shut down for night.

25-Sep-00 Depth: 800

Removed BOPE stack from cellar. Cut off wellhead flange from 13-3/8" casing. Loaded rental equipment on transport for shipment to vendor. Rigged up to run 9-5/8" liner. Welded guide shoe on bottom of first joint of perforated $95 / 8$ " liner. Ran two (2) joints of 9-5/8" casing into wellbore. Shut down for night.

26-Sep-00 Depth: 800

Continued running 9 5/8" blank and perforated liner. Made up liner adapter and adapter setting tool. Ran liner in hole on drill pipe. Set liner on bottom with shoe at 793', top of liner adapter at 395'. Perforated 9-5/8" liner interval from 793' to 562'. Released liner adapter. Pulled out of hole with drill pipe and setting tool. Broke down running tools. Laid down derrick. Plan to weld plate on top of $13-3 / 8$ " casing. 

APPENDIX 2

SUMMARY GEOLOGIC LOG OF THE MASSON 36 WELL 


\section{SUMMARY GEOLOGIC LOG OF MASSON 36 WELL}

\section{4 to 14 feet}

ALLUVIUM unconsolidated fluvial sand and gravel; arroyo deposits and drill pad base.

\section{4 to 120 feet}

PALM PARK FM Altered and slightly-to moderately indurated purple brown and blue green, clayey andesitic volcanolitharenite and volcanolithrudite; mostly interbedded andesitic breccia mudflow or lahar deposits.

\section{0 to 222 feet}

ROBLEDO RHYOLITE Grey porphyritic rhyolite. Highly fractured with brown and red brown oxidized fracture and breccia fragment surfaces. Rhyolite dike with shallow north dip.

\section{2 to 495 feet}

PALM PARK FM Altered and indurated brown andesitic volcanolitharenite and volcanolithrudite with intervals of strong blue green chlorite, epidote and clay alteration; mostly interbedded with andesitic breccia mud flow or lahar deposits.

\section{5 to 635 feet}

PALM PARK FM Altered purple brown, maroon and brown, indurated andesitic volcanolitharenite and volcanolithrudite with intervals of strong blue green chlorite, epidote, and clay alteration; mostly interbedded with andesitic breccia mud flow or lahar deposits. 


\section{5 to 710 feet}

PALM PARK FM Interbedded light gray to brown arkosic litharenite and purple brown andesitic volcanolitharenite with some strong blue green alteration; very minor disseminated hydrothermal pyrite mineralization below 690 feet.

\section{0 to 788 feet}

LOVE RANCH FM Granule, fine to medium arkosic lithic sandstone with some clastic chert and minor disseminated hydrothermal pyrite mineralization. 788 to 800 feet

HUECO FM Limestone with gray sticky clay. 
APPENDIX 3

LABORATORY ANALYSIS OF WATER AND OTHER SAMPLES 


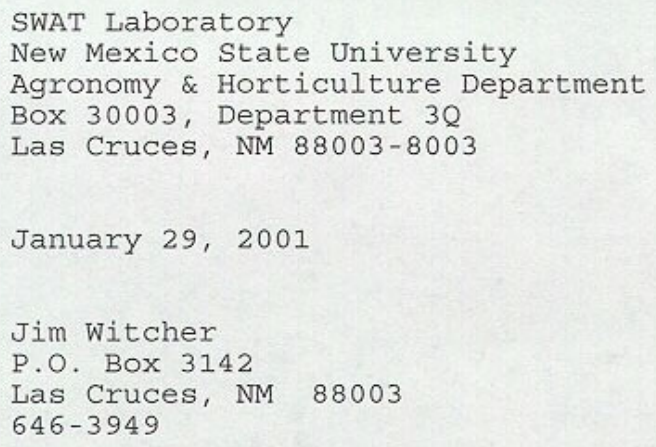

PARAM"

Please advise should you have questions concerning these data.

Respectfully submitted,

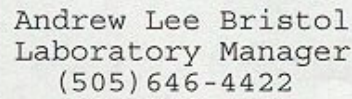




\begin{tabular}{|c|c|c|c|c|c|}
\hline X-Ray Diffraction L & $a b$ & & Operating conditions: & & \\
\hline Department of Ear & th Sciences & & kV & 30 & \\
\hline New Mexico State & University & & $\mathrm{mA}$ & 40 & \\
\hline Dr. Nancy J. McMi & Ilan & & scan rate & 2deg/min & \\
\hline (505) 646-5000 & & & full scale & $800 \mathrm{cps}$ & \\
\hline & & & chart speed & $2 \mathrm{~mm} / \mathrm{min}$ & \\
\hline & & & Analyst: & McMillan & \\
\hline Name: & Jim Witcher & & Interpreted by: & McMillan & \\
\hline Sample No. & clay & & & & \\
\hline Minerals present: & quartz, montmorilloni & & & & \\
\hline & & & & & \\
\hline & note - the mont & tmorillonite 2 & roak at 7.4320 & ceste 1 & \\
\hline & & & & & \\
\hline $2 \theta$ & d & Mineral & $\mathrm{d}$ or $2 \theta$, matched peak & & \\
\hline 20.1 & 4.413849944 & montmorillonite & 19.95 & & \\
\hline 21.1 & 4.206866805 & quartz & 20.85 & & \\
\hline 26.9 & 3.311525599 & quartz & 26.66 & & \\
\hline 29.7 & 3.005391876 & montmorillonite & 30.09 & & \\
\hline 35.2 & 2.547376652 & montmorillonite & 35.05 & & \\
\hline 36.8 & 2.440210201 & quartz & 36.56 & & \\
\hline 39.7 & 2.268384308 & quartz & 39.49 & & \\
\hline 40.5 & 2.225403182 & quartz & 2.237 & & \\
\hline 42.6 & 2.120433285 & quartz & 2.212 & & \\
\hline 43.4 & 2.08318257 & $? ?$ & & & \\
\hline 46 & 1.971304418 & quartz & 1.98 & & \\
\hline 50.4 & 1.809035844 & quartz & 50.21 & & \\
\hline 55.2 & 1.662543906 & quartz & 1.672 & & \\
\hline 60.2 & 1.53585944 & quartz & 1.541 & & \\
\hline 64.3 & 1.447463881 & quartz & 1.453 & & \\
\hline 68.5 & 1.368591429 & quartz & 68.2 & & \\
\hline & & & & & \\
\hline & & & & & \\
\hline & . & & & & \\
\hline & & & & & \\
\hline & & & & & \\
\hline & & & & & \\
\hline & & & & & \\
\hline & & & & & \\
\hline & & & & & \\
\hline & & & & & \\
\hline & & & & & \\
\hline & & & & & \\
\hline & & & & & \\
\hline & & & & & \\
\hline & & & & & \\
\hline & & & & & \\
\hline & & & & & \\
\hline & & & & & \\
\hline & & & & & \\
\hline & & & & & \\
\hline
\end{tabular}




\begin{tabular}{|c|c|c|c|c|c|}
\hline \multicolumn{2}{|c|}{ X-Ray Diffraction Lab } & & \multicolumn{2}{|l|}{ Operating conditions: } & \\
\hline \multicolumn{2}{|c|}{ Department of Earth Sciences } & & kV & 30 & \\
\hline \multicolumn{2}{|c|}{ New Mexico State University } & & $\mathrm{mA}$ & 40 & \\
\hline \multicolumn{2}{|c|}{ Dr. Nancy J. McMillan } & & scan rate & $2 \mathrm{deg} / \mathrm{min}$ & \\
\hline \multirow[t]{3}{*}{ (505) $646-5000$} & & & full scale & $800 \mathrm{cps}$ & \\
\hline & & & chart speed & $2 \mathrm{~mm} / \mathrm{min}$ & \\
\hline & & & Analyst: & McMillan & \\
\hline Name: & Jim Witcher & & Interpreted by: & McMillan & \\
\hline Sample No. & scaling & & & & \\
\hline Minerais present: & calcite, aragonite & & & & \\
\hline & & & & & \\
\hline & & & & & \\
\hline & & & & & \\
\hline $2 \theta$ & d & Mineral & d or $2 \theta$, matched peak & & \\
\hline 26.4 & 3.373098599 & aragonite & 26.24 & & \\
\hline 27.4 & 3.252221033 & aragonite & 27.25 & & \\
\hline 29.7 & 3.005391876 & calcite & 29.43 & & \\
\hline 33.4 & 2.680430841 & aragonite & 33.18 & & \\
\hline 36.4 & 2.466102745 & calcite & 36 & & \\
\hline 38.2 & 2.353936024 & aragonite & 37.93 & & \\
\hline 38.8 & 2.31890467 & aragonite & $2.34,2.33$ & & \\
\hline 39.7 & 2.268384308 & calcite & 39.43 & & \\
\hline 46.1 & 1.967260738 & aragonite & 45.6 & & \\
\hline 47.7 & 1.904939286 & calcite & 47.53 & & \\
\hline 48.7 & 1.868135234 & calcite & 48.55 & & \\
\hline 50.4 & 1.809035844 & aragonite & 1.814 & & \\
\hline 52.8 & 1.73231907 & aragonite & $1.742,1.728$ & & \\
\hline 57.9 & 1.591273771 & calcite & 1.604 & & \\
\hline 61.1 & 1.515374834 & calcite & 1.525 & & \\
\hline 43.4 & 2.08318257 & calcite & 43.18 & & \\
\hline & & & & & \\
\hline & & & & & \\
\hline & + & & & & \\
\hline & & & & & \\
\hline & & & & & \\
\hline & & & & & \\
\hline & & & & & \\
\hline & & & & & \\
\hline & & & & & \\
\hline & & & & & \\
\hline & & & & & \\
\hline & & & & & \\
\hline & & & & & \\
\hline & & & & & \\
\hline & & & & & \\
\hline & & & & & \\
\hline & & & & & \\
\hline & & & & & \\
\hline & & & & & \\
\hline & & & & & \\
\hline
\end{tabular}


APPENDIX 4

DOWELL/SCHLUMBERGER SURFACE CASING CEMENT REPORT 


\title{
Schlumberger
}

\section{DESIGN - EXECUTE - EVALUATE - REPORT \\ CEMENTING \\ SURFACE 13 3/8}

\author{
K D HUEY \\ MASSON 36 \\ DONA ANNA COUNTY, NEW MEXICO
}

Prepared By: R KURT CROWE

SERVICE SUPERVISOR

ARTESIA DISTRICT

505-748-1392

AUGUST 31, 2000 


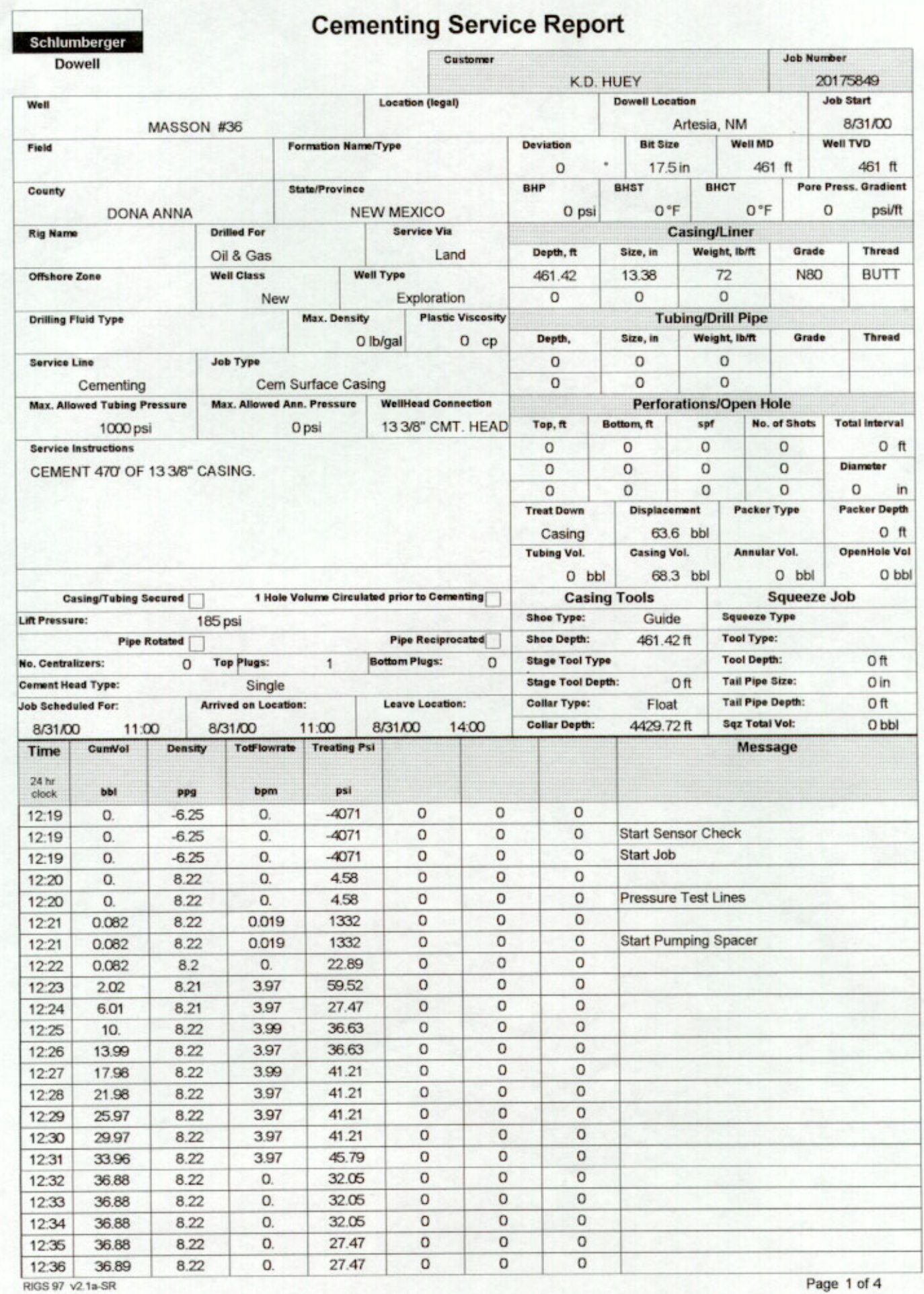




\begin{tabular}{|c|c|c|c|c|c|c|c|c|c|}
\hline Well & \multicolumn{2}{|c|}{ MASSON \#\#36 } & \multicolumn{2}{|c|}{ Field } & & Service Date & \multicolumn{2}{|r|}{ K.D. HUEY } & $\begin{array}{l}\text { Job Number } \\
\qquad 20175849\end{array}$ \\
\hline Time & Cumvol & Density & Totflowrate & Treating Psi & & & & Mes: & \\
\hline $\begin{array}{l}24 \mathrm{hr} \\
\text { clock }\end{array}$ & bbl & ppg & bpm & psi & & & & & \\
\hline 12.37 & 36.89 & 8.22 & 0. & 27.47 & 0 & 0 & 0 & & \\
\hline $12: 38$ & 40.44 & 8.22 & 3.99 & 50.37 & 0 & 0 & 0 & & \\
\hline $12: 39$ & 44.44 & 8.22 & 3.99 & 54.95 & 0 & 0 & 0 & & \\
\hline $12: 40$ & 48.43 & 8.22 & 3.97 & 54.96 & 0 & 0 & 0 & & \\
\hline $12: 41$ & 52.42 & 8.23 & 3.97 & 59.52 & 0 & 0 & 0 & & \\
\hline $12: 42$ & 56.41 & 8.2 & 3.99 & 59.52 & 0 & 0 & 0 & & \\
\hline $12: 43$ & 60.4 & 8.2 & 3.97 & 59.52 & 0 & 0 & 0 & & \\
\hline $12: 44$ & 64.4 & 8.2 & 3.97 & 59.52 & 0 & 0 & 0 & & \\
\hline $12: 45$ & 68.39 & 8.2 & 3.97 & 59.52 & 0 & 0 & 0 & & \\
\hline $12: 46$ & 72.38 & 8.17 & 3.97 & 59.52 & 0 & 0 & 0 & & \\
\hline $12: 47$ & 72.38 & 8.17 & 3.97 & 59.52 & 0 & 0 & 0 & End Spacer & \\
\hline $12: 47$ & 72.38 & 8.17 & 3.97 & 59.52 & 0 & 0 & 0 & Start Mixing Lead Slurry & \\
\hline $12: 47$ & 76.38 & 11.12 & 3.97 & 59.52 & 0 & 0 & 0 & & \\
\hline $12: 48$ & 4.8 & 14.61 & 5.72 & 100.7 & 0 & 0 & 0 & & \\
\hline $12: 49$ & 10.32 & 14.84 & 5.48 & 100.7 & 0 & 0 & 0 & & \\
\hline 12.50 & 15.84 & 14.7 & 5.48 & 91.58 & 0 & 0 & 0 & & \\
\hline 1251 & 21.36 & 14.54 & 5.48 & 91.58 & 0 & 0 & 0 & & \\
\hline 12.52 & 26.88 & 14.55 & 5.48 & 91.58 & 0 & 0 & 0 & & \\
\hline 1253 & 32.4 & 14.67 & 5.58 & 87. & 0 & 0 & 0 & & \\
\hline 1254 & 37.92 & 14.39 & 5.48 & 82.42 & 0 & 0 & 0 & & \\
\hline 1255 & 43.44 & 14.26 & 5.5 & 77.84 & 0 & 0 & 0 & & \\
\hline 1256 & 48.97 & 14.82 & 5.5 & 87. & 0 & 0 & 0 & & \\
\hline 12.57 & 54.48 & 14.44 & 5.48 & 82.42 & 0 & 0 & 0 & & \\
\hline 1258 & 60. & 14.55 & 55 & 87. & 0 & 0 & 0 & & \\
\hline 1259 & 65.52 & 14.8 & 5.48 & 87. & 0 & 0 & 0 & & \\
\hline 13.00 & 71.04 & 14.55 & 5.48 & 91.58 & 0 & 0 & 0 & & \\
\hline 13.00 & 71.04 & 14.55 & 5.48 & 91.58 & 0 & 0 & 0 & End Lead Slurry & \\
\hline $13: 00$ & 71.04 & 14.55 & 5.48 & 91.58 & 0 & 0 & 0 & Start Moxing Tail Slurry & \\
\hline 13.01 & 208 & 16.12 & 3.97 & 73.26 & 0 & 0 & 0 & & \\
\hline 13.02 & 7.28 & 16.45 & 5.46 & 146.5 & 0 & 0 & 0 & & \\
\hline 13.03 & 128 & 13.71 & 5.48 & 82.42 & 0 & 0 & 0 & & \\
\hline 13.04 & 18.32 & 16.04 & 5.48 & 123.6 & 0 & 0 & 0 & & \\
\hline 13.05 & 23.84 & 15.64 & 5.48 & 123.6 & 0 & 0 & 0 & & \\
\hline 13.06 & 29.38 & 15.77 & 5.48 & 137.4 & 0 & 0 & 0 & & \\
\hline 13.07 & 34.55 & 16.04 & 5.6 & 109.9 & 0 & 0 & 0 & & \\
\hline $13: 08$ & 40.05 & 15.35 & 4.3 & 109.9 & 0 & 0 & 0 & & \\
\hline 13.09 & 44.45 & 16.25 & 3.97 & 105.3 & 0 & 0 & 0 & & \\
\hline $13: 10$ & 49.12 & 16.24 & 5.48 & 155.7 & 0 & 0 & 0 & & \\
\hline $13: 11$ & 53.85 & 16.23 & 3.97 & 96.15 & 0 & 0 & 0 & & \\
\hline $13: 12$ & 58.13 & 16.17 & 3.97 & 96.15 & 0 & 0 & 0 & & \\
\hline $13: 13$ & 62.12 & 16.31 & 3.97 & 114.5 & 0 & 0 & 0 & & \\
\hline $13: 13$ & 62.12 & 16.31 & 3.97 & 114.5 & 0 & 0 & 0 & End Tail Slurry & \\
\hline $13: 13$ & 62.12 & 16.31 & 3.97 & 114.5 & 0 & 0 & 0 & Shutdown & \\
\hline $13: 13$ & 62.12 & 16.31 & 3.97 & 114.5 & 0 & 0 & 0 & Drop Top Plug & \\
\hline $13: 14$ & 62.12 & 16.31 & 3.97 & 114.5 & 0 & 0 & 0 & Start Displacement & \\
\hline $13: 14$ & 0.002 & 15.54 & 0. & 36.63 & 0 & 0 & 0 & & \\
\hline $13: 15$ & 0.002 & 12.72 & 0. & 54.95 & 0 & 0 & 0 & & \\
\hline $13: 16$ & 2.97 & 9.91 & 3.97 & 54.95 & 0 & 0 & 0 & & \\
\hline $13: 17$ & 6.98 & 8.51 & 3.97 & 50.37 & 0 & 0 & 0 & & \\
\hline $13: 18$ & 10.97 & 8.24 & 4.16 & 50.37 & 0 & 0 & 0 & & \\
\hline $13: 19$ & 14.97 & 8.2 & 3.97 & 59.52 & 0 & 0 & 0 & & \\
\hline $13: 19$ & 14.97 & 8.2 & 3.97 & 59.52 & 0 & 0 & 0 & Pressure and Rate & \\
\hline $13: 20$ & 18.97 & 8.18 & 3.97 & 82.42 & 0 & 0 & 0 & & \\
\hline $13: 21$ & 22.96 & 8.21 & 3.99 & 100.7 & 0 & 0 & 0 & & \\
\hline
\end{tabular}

Page 2 of 4 


\begin{tabular}{|c|c|c|c|c|c|c|c|c|c|}
\hline Well & \multicolumn{2}{|c|}{ MASSON \#\#36 } & \multicolumn{2}{|c|}{ Field } & & Service Date & & K.D. HUEY & $\begin{array}{l}\text { Job Number } \\
\qquad 20175849\end{array}$ \\
\hline Time & Cumvol & Density & Totf lowrate & Treating Psi & & & & & \\
\hline $\begin{array}{l}24 \mathrm{hr} \\
\text { clock }\end{array}$ & bbi & ppg & bpm & psi & & & & & \\
\hline 13.22 & 26.95 & 8.21 & 3.97 & 123.6 & 0 & 0 & 0 & & . \\
\hline $13: 23$ & 32.33 & 8.21 & 3.97 & 155.7 & 0 & 0 & 0 & & \\
\hline 13.24 & 36.32 & 8.21 & 3.97 & 169,4 & 0 & 0 & 0 & & \\
\hline 13.25 & 36.32 & 8.21 & 3.97 & 169.4 & 0 & 0 & 0 & Lower Pump Rate & \\
\hline 13.25 & 39.9 & 8.21 & 1.94 & 128.2 & 0 & 0 & 0 & & \\
\hline 13.26 & 41.93 & 8.21 & 2.02 & 123.6 & 0 & 0 & 0 & & \\
\hline $13: 27$ & 43.96 & 8.21 & 2. & 141.9 & 0 & 0 & 0 & & \\
\hline $13: 28$ & 45.3 & 8.21 & 0. & 109.9 & 0 & 0 & 0 & & \\
\hline $13: 28$ & 45.3 & 8.21 & 0. & 109.9 & 0 & 0 & 0 & S/D WOC & \\
\hline $13: 29$ & 45.3 & 8.21 & 0. & 91.58 & 0 & 0 & 0 & & \\
\hline $13: 30$ & 45.3 & 8.21 & 0. & 87. & 0 & 0 & 0 & & \\
\hline 13.31 & 45.3 & 8.21 & 0. & 82.42 & 0 & 0 & 0 & & \\
\hline 13.32 & 45.3 & 8.21 & 0. & 82.42 & 0 & 0 & 0 & & \\
\hline 13.33 & 45.3 & 8.21 & 0. & 77.84 & 0 & 0 & 0 & & \\
\hline 13.34 & 45.3 & 8.21 & 0. & 77.84 & 0 & 0 & 0 & & \\
\hline $13: 35$ & 45.3 & 8.21 & 0. & 77.84 & 0 & 0 & 0 & & \\
\hline 13.36 & 45.3 & 8.21 & 0. & 77.84 & 0 & 0 & 0 & & \\
\hline 13.37 & 45.3 & 8.21 & 0. & 77.84 & 0 & 0 & 0 & & \\
\hline 13.38 & 45.3 & 8.21 & 0. & 77.84 & 0 & 0 & 0 & Resume Flush & \\
\hline 13.38 & 45.3 & 8.21 & 0. & 77.84 & 0 & 0 & 0 & & \\
\hline 13.39 & 47.05 & 8.21 & 2.02 & 174. & 0 & 0 & 0 & & \\
\hline $13: 40$ & 49.08 & 8.21 & 2.02 & 192.3 & 0 & 0 & 0 & & \\
\hline 13.41 & 51.11 & 8.21 & 2.02 & 187.7 & 0 & 0 & 0 & & \\
\hline 13.42 & 53.14 & 8.21 & 2.02 & 196.9 & 0 & 0 & 0 & & \\
\hline $13: 43$ & 55.18 & 8.21 & 2.02 & 210.6 & 0 & 0 & 0 & & \\
\hline $13: 43$ & 55.18 & 8.21 & 2.02 & 210.6 & 0 & 0 & 0 & S/D WOC & \\
\hline $13: 44$ & 55.26 & 8.21 & 0. & 119. & 0 & 0 & 0 & & \\
\hline 13.45 & 55.26 & 8.21 & 0. & 105.3 & 0 & 0 & 0 & & \\
\hline $13: 46$ & 55.26 & 8.21 & 0. & 105.3 & 0 & 0 & 0 & & \\
\hline $13: 47$ & 55.26 & 8.21 & 0. & 105.3 & 0 & 0 & 0 & & \\
\hline $13: 48$ & 55.26 & 8.21 & 0. & 105.3 & 0 & 0 & 0 & & \\
\hline $13: 49$ & 55.26 & 8.21 & 0. & 105.3 & 0 & 0 & 0 & & \\
\hline $13: 50$ & 55.26 & 8.21 & 0. & 105.3 & 0 & 0 & 0 & & \\
\hline 13.51 & 55.26 & 8.21 & 0. & 105.3 & 0 & 0 & 0 & & \\
\hline 13.52 & 55.26 & 8.21 & 0. & 105.3 & 0 & 0 & 0 & & \\
\hline 13.53 & 55.26 & 8.21 & 0. & 105.3 & 0 & 0 & 0 & Resume Flush & \\
\hline 13.53 & 55.32 & 8.21 & 1.03 & 109.9 & 0 & 0 & 0 & & \\
\hline 13.54 & 57.16 & 8.21 & 1.94 & 283.9 & 0 & 0 & 0 & & \\
\hline 13.55 & 59.12 & 8.21 & 1.96 & 224.4 & 0 & 0 & 0 & & \\
\hline 13.56 & 61.08 & 8.21 & 1.94 & 224.4 & 0 & 0 & 0 & & \\
\hline 13.57 & 63.04 & 8.21 & 1.94 & 238.1 & 0 & 0 & 0 & & \\
\hline 13.58 & 65. & 8.21 & 1.94 & 274.7 & 0 & 0 & 0 & & \\
\hline 13.59 & 65. & 8.21 & 1.94 & 274.7 & 0 & 0 & 0 & Bump Top Plug & \\
\hline 13.59 & 65. & 8.21 & 1.94 & 274.7 & 0 & 0 & 0 & Bleed Off Pressure & \\
\hline $13: 59$ & 0. & 8.21 & 0. & 572.3 & 0 & 0 & 0 & & \\
\hline
\end{tabular}




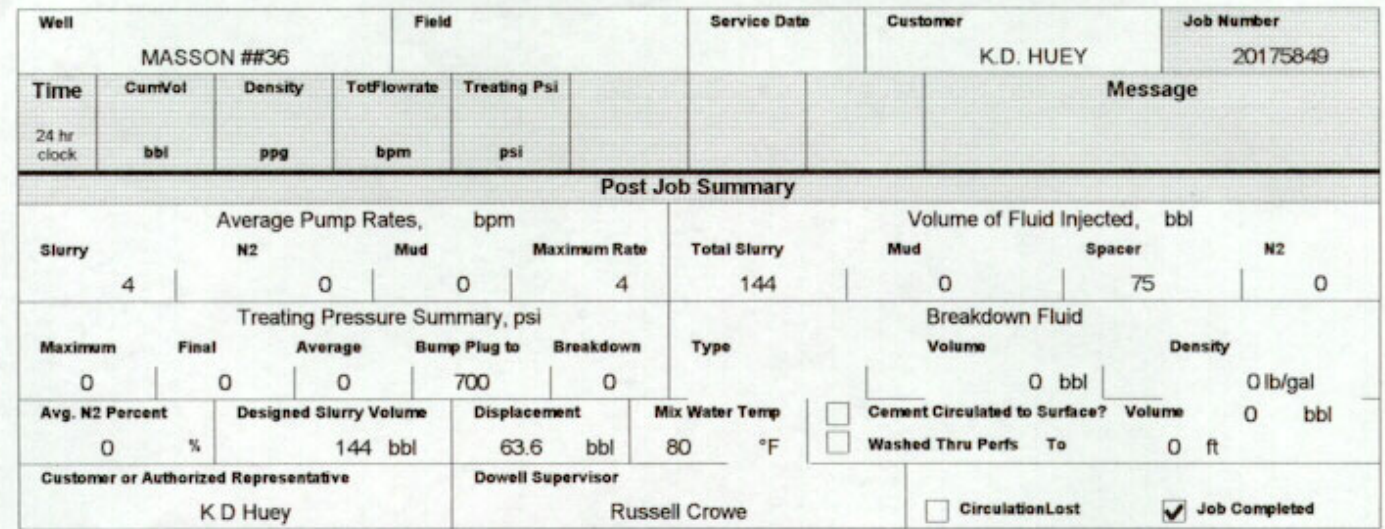




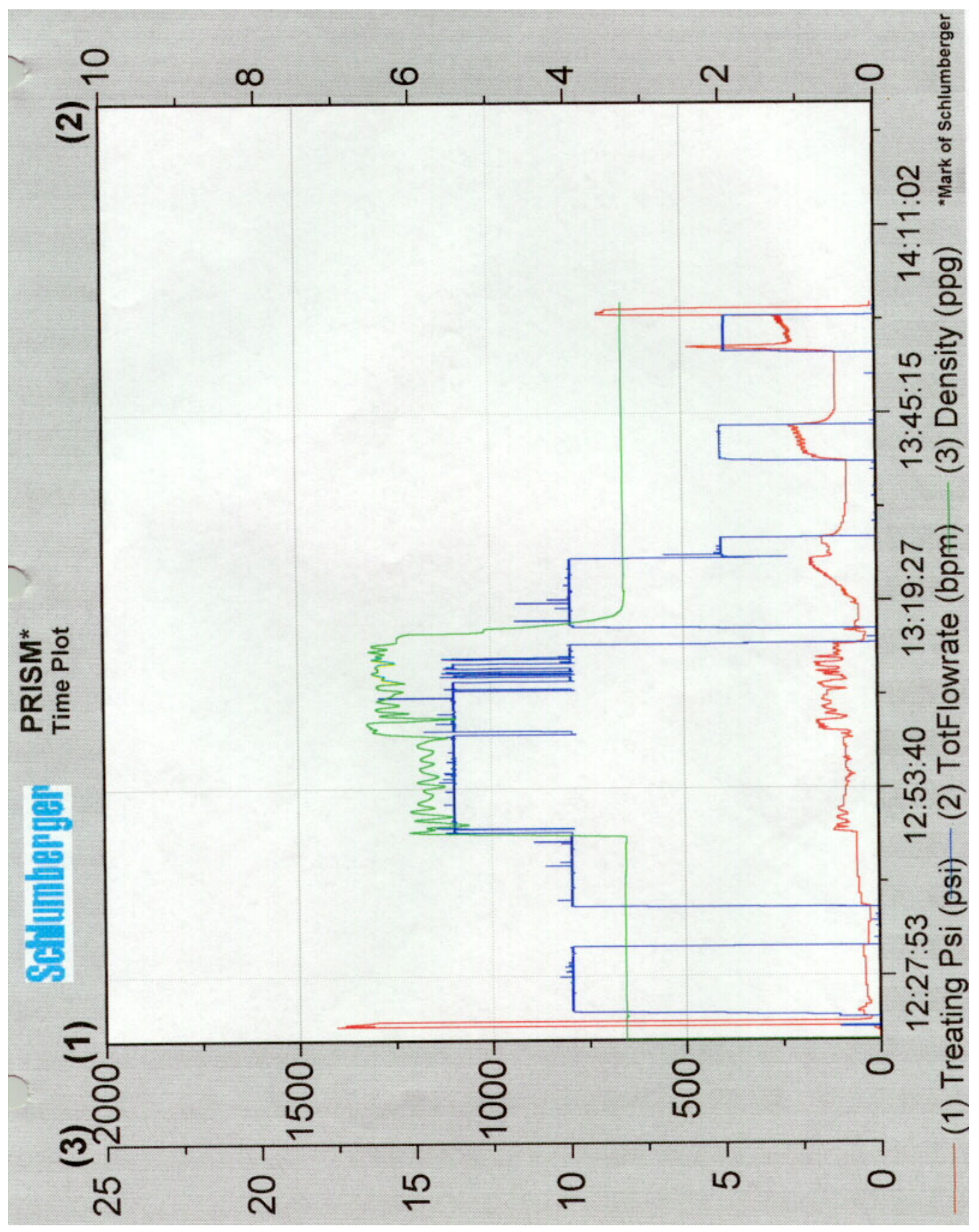

